\title{
Reference
}

NBS

Publi-

cations

A】l孔0】 987344

NBSIR 83-2715

\section{Smoke Control for Elevators}

U.S. DEPARTMENT OF COMMERCE

National Bureau of Standards

National Engineering Laboratory

Center for Fire Research

Washington, DC 20234

June 1983

Prepared for

Veterans Administration

Office of Construction $\mathrm{OBH}$

Washington, DC 20420 



\section{SMOKE CONTROL FOR ELEVATORS}

$\ldots 0$

John H. Klote

U.S. DEPARTMENT OF COMMERCE

National Bureau of Standards

National Engineering Laboratory

Center for Fire Research

Washington, DC 20234

June 1983

Prepared for:

Veterans Administration

Office of Construction $08 \mathrm{H}$

Washington, DC 20420

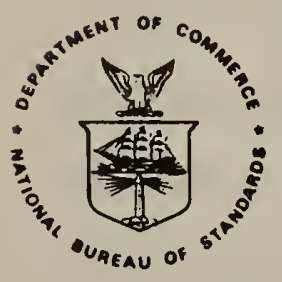

U.S. DEPARTMENT OF COMMERCE, Malcolm Baldrige, Secretary NATIONAL BUREAU OF STANDARDS, Ernest Ambler, Director 

LIST OF FIGURES $\ldots \ldots \ldots \ldots \ldots \ldots \ldots \ldots \ldots \ldots \ldots \ldots \ldots \ldots \ldots \ldots \ldots \ldots \ldots \ldots$

LIST OF TABLES $\ldots \ldots \ldots \ldots \ldots \ldots \ldots \ldots \ldots \ldots \ldots \ldots \ldots \ldots \ldots \ldots \ldots \ldots \ldots \ldots$

Abstract $\ldots \ldots \ldots \ldots \ldots \ldots \ldots \ldots \ldots \ldots \ldots \ldots \ldots \ldots \ldots \ldots \ldots \ldots \ldots \ldots \ldots \ldots \ldots$

1. InTRUDUCTION $\ldots \ldots \ldots \ldots \ldots \ldots \ldots \ldots \ldots \ldots \ldots \ldots \ldots \ldots \ldots \ldots \ldots \ldots \ldots \ldots \ldots$

2. PROBLEMS WITH ELEVATORS $\ldots \ldots \ldots \ldots \ldots \ldots \ldots \ldots \ldots \ldots \ldots \ldots \ldots \ldots$

3. CONCEPTUAL SOLUTiON $\ldots \ldots \ldots \ldots \ldots \ldots \ldots \ldots \ldots \ldots \ldots \ldots \ldots \ldots \ldots \ldots \ldots$

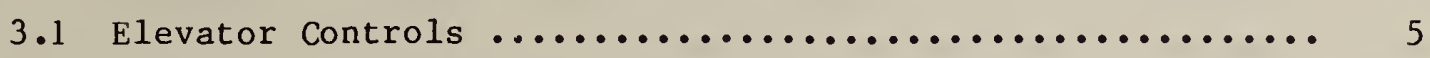

3.2 Electric Power .................................. 5

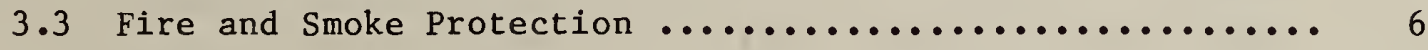

4. FIELD TESTS $\ldots \ldots \ldots \ldots \ldots \ldots \ldots \ldots \ldots \ldots \ldots \ldots \ldots \ldots \ldots \ldots \ldots \ldots$

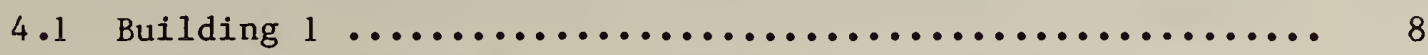

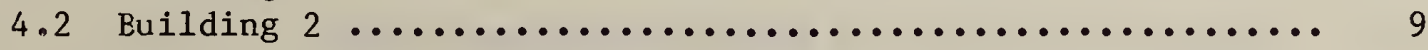

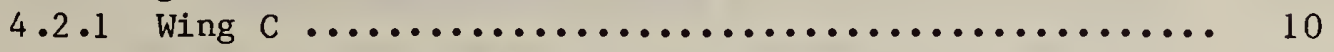

4.2.1.1 All Smoke Control Systems Operating ..... 10

4.2.1.2 Stairwell Pressurization and

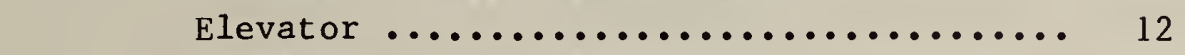

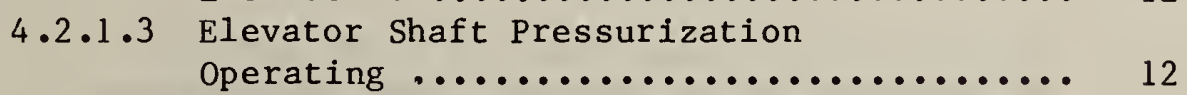

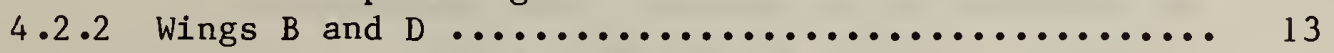

4.2 .2 .1 Pressurized Stairwells $\ldots \ldots \ldots \ldots \ldots \ldots \ldots \ldots 14$

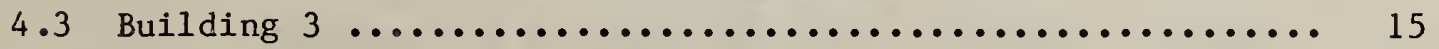

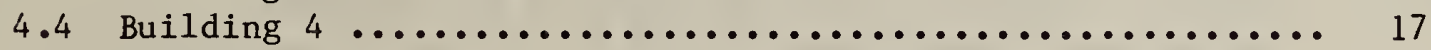

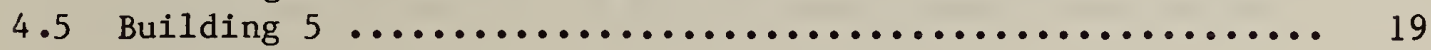

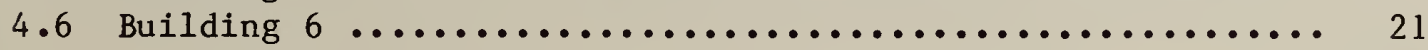

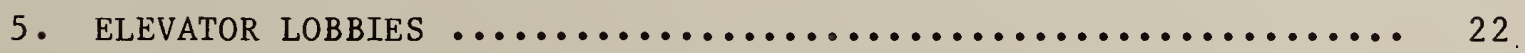

5.1 Pressure Differences ........................... 23

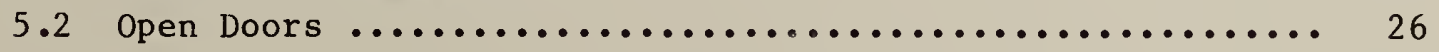

6. HORIZONTAL PRESSURE PROFILES....................... 26

7. VERTICAL PRESSURE PROFILES $\ldots \ldots \ldots \ldots \ldots \ldots \ldots \ldots \ldots \ldots \ldots \ldots \ldots \ldots \ldots$

8. CONCLUSIONS $\ldots \ldots \ldots \ldots \ldots \ldots \ldots \ldots \ldots \ldots \ldots \ldots \ldots \ldots \ldots \ldots \ldots \ldots \ldots \ldots \ldots \ldots$

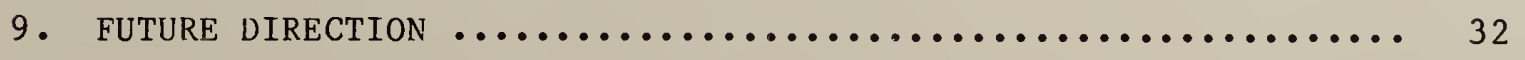

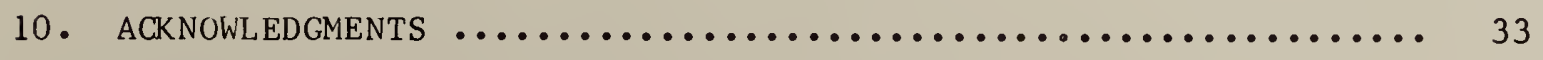

11. REFERENCES $\ldots \ldots \ldots \ldots \ldots \ldots \ldots \ldots \ldots \ldots \ldots \ldots \ldots \ldots \ldots \ldots \ldots \ldots \ldots \ldots \ldots \ldots$ 
Figure 1. Floor plans for building $1 \ldots \ldots \ldots \ldots \ldots \ldots \ldots \ldots \ldots$

Figure 2. Floor plan for first floor for building $2 \ldots \ldots \ldots \ldots$

Figure 3. Typical floor plan above the first floor for

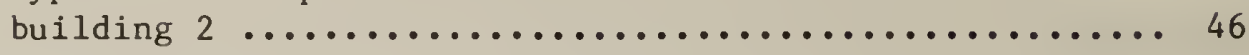

Figure 4 . First floor plan for building $3 \ldots \ldots \ldots \ldots \ldots \ldots$

Figure 5. Typical floor plan above the first floor for

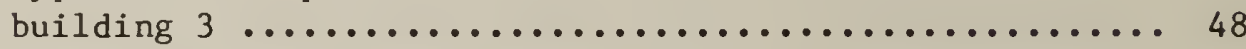

Figure 6 . Typical floor plan for building $4 \ldots \ldots \ldots \ldots \ldots \ldots \ldots$

Figure 7. Floor plan for ground level of building $5 \ldots \ldots \ldots \ldots$

Figure 8. Typical floor plan for floors 3 through 19 of

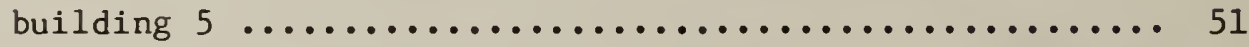

Figure 9. Typical floor plan for floors 20 through 36 of

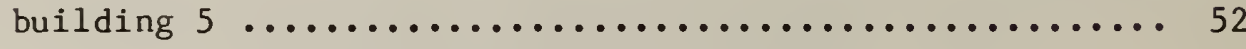

Figure 10 . Elevation of building $6 \ldots \ldots \ldots \ldots \ldots \ldots \ldots \ldots \ldots$

Figure 11. Relationship between flow areas and pressure differences for an elevator lobby pressurized indirectly through the elevator shaft ............. 54

Figure 12. Pressure difference from the shaft to the outside during winter conditions $\left(\mathrm{T}_{0}<\mathrm{T}_{\mathrm{s}}\right) \ldots \ldots \ldots \ldots \ldots \ldots \ldots \ldots$ 
Table 1. Pressure across elevator doors of building $1 \ldots \ldots \ldots$

Table 2. Pressures in wing $C$ of building 2 with all smoke

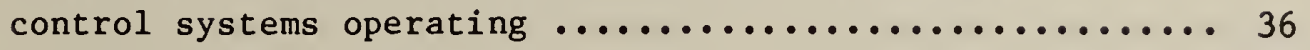

Table 3. Pressures in wing $C$ of building 2 with the corridor pressurization system not operating ............... 37

Table 4. Pressures in wing $C$ of building 2 with only the

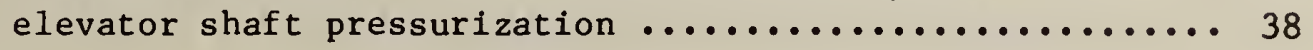

Table 5. Pressures in wings $B$ and $D$ of building $2 \ldots \ldots \ldots \ldots$

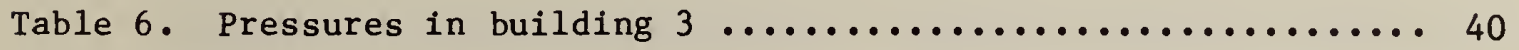

Table 7. Pressures in building $4 \ldots \ldots \ldots \ldots \ldots \ldots \ldots \ldots \ldots \ldots \ldots$

Table 8. Pressure differences from building $5 \ldots \ldots \ldots \ldots \ldots \ldots \ldots$

Table 9. Pressure differences from building $6 \ldots \ldots \ldots \ldots \ldots \ldots \ldots$ 


\section{SMOKE CONTROL FOR ELEVATORS \\ John H. Klote \\ National Bureau of Standards Washington, D.C. 20234}

This paper is the second report of an ongoing project at the National Bureau of Standards (NBS) to investigate the use of smoke control in an attempt to allow the use of elevators as a means of fire escape for the handicapped. The use of stairwells for fire evacuation poses a problem for people who cannot use stairs because of physical disabilities. This paper discusses some of the major problems associated with the use of elevators as a means of fire exit and proposes a conceptual solution to those problems. A report is made on field tests of six buildings with elevator protection systems. A simple relationship is developed for the pressure differences across the elevator shaft and across the elevator lobby for one type of elevator pressurization system. Vertical pressure profiles of such systems are also discussed.

Key words: Building fires; elevators (1ifts); egress; evacuation; handicapped; pressurization; smoke control; stairwe1ls. 
In most elevator lobbies in the United States there are signs which have statements similar to the following:

\author{
- WARNING - \\ ELEVATOR SHALL NOT BE \\ USED IN THE EVENT OF FIRE \\ USE MARKED EXIT STAIRWAYS
}

\begin{abstract}
Unfortunately some people cannot use stairs because of physical disabilities. Because of this problem, the Veterans Administration (VA) is sponsoring a project at the National Bureau of Standards (NBS), Center for Fire Research (CFR) to investigate the feasibility of using elevators as a means of fire exit for the physically handicapped. The ultimate goal of this project is to provide information which can be used by building designers.
\end{abstract}

This paper is the second report on this project. The first report [1] 1 contained a brief discussion of the problem, presentation of a conceptual solution, and a report of field tests on four buildings which have smoke control systems intended to protect elevators during fire situations. The information from the first report is presented herein as a convenience to the reader. In addition, this paper contains a report of field tests on two additional buildings. A simple relationship is developed for the pressure differences across an elevator shaft and the elevator lobby, and vertical pressure profiles are also discussed. Some of the buildings tested had other

\footnotetext{
${ }^{1}$ Numbers in brackets refer to the literature references listed at the end of this paper.
} 
types of smoke control systems in addition to systems for elevator protection. These systems are also discussed in terms of their interaction with the elevator protection system.

\section{PROBLEMS WITH ELEVATORS}

The National Fire Protection Association (NFPA), Life Safety Code (NFPA 101-1976) [2] lists the following problems involved with the use of elevators as fire exits.

1. "Persons seeking to escape from a fire by means of an elevator may have to wait at the elevator door for some time, during which they may be exposed to fire or smoke, or panic may develop.

2. Automatic elevators respond to the pressing of buttons in such a way that it would be quite possible for an elevator in use for descent from floors above a fire to stop automatically at the floor involved in the fire and the doors to open automatically exposing occupants to fire and smoke.

3. Modern elevators cannot start until doors are fully closed. A large number of people seeking to crowd into an elevator in case of emergency might make it impossible to start. 
4. Any power failure, such as the burning out of electric supply cables during a fire, may render the elevators inoperative or might result in trapping persons in elevators stopped between floors. Under fire conditions there might not be time to permit rescue of trapped occupants through emergency escape hatches or doors."

It is common practice for elevators serving more than three floors to automatically descend to the ground floor in the event of a fire ${ }^{2}$. Fire fighters have keys with which they can manually control elevators and use them during building evacuation and fire fighting. However, smoke infiltration into elevator shafts frequently threatens life and hinders elevator use by fire fighters.

It is also current practice to provide top vents in elevator shafts serving more than three floors ${ }^{3}$. The intent of such venting is to allow the elevator shaft to act as a smoke shaft, carrying smoke from the fire floor out of the building. However, because of leakage around elevator doors this feature may significantly contribute to smoke movement to floors beyond the fire floor by way of the elevator shaft itself.

The operation of elevators under fire conditions is mandated by section 211.3 of ANSI Al7.1 [3].

${ }^{3}$ The requirement for vents in elevator shafts is listed in section 100.4 of ANSI Al7.1 [3]. 
In order to overcome the problems discussed in the proceeding section, an elevator system used as a fire exit needs to have the following attributes:

1. Elevator control must assure safe and efficient evacuation.

2. Reliable electric power must be supplied.

3. Elevator lobbies and the elevator shaft must be protected against fire and smoke.

\subsection{Elevator Controls}

The elevator can be controlled so that it will descend to the ground floor in the event of a fire alarm. Fire department or other authorized personnel can then use the elevators for evacuation. With the elevators controlled by authority figures, the likelihood that a large number of people would crowd into the elevator and make it impossible to close the doors will probably be reduced.

\subsection{Electric Power}

Considerable experience exists in assuring the supply of electrical power for critical functions in hospitals, communication facilities, computer facilities, and the like. The most common methods employed are emergency batteries, emergency generators, and multiple power feeds. While it is beyond 
the scope of this paper to examine methods of assuring power reliability, it appears that state-of-the-art solutions are available for elevator systems.

\subsection{Fire and Smoke Protection}

Considerable information is available concerning the fire resistance of walls, partitions, floors, doors, etc. The ability to design and build elevator lobbies and elevator shafts that can withstand severe building fires has existed for years. Even though smoke protection is a more difficult problem, smoke movement across a barrier can be prevented by the use of pressure differences as discussed in section 5.1.

In implementing elevator shaft pressurization, the jamming of elevator doors in the open position can be a potential problem. The forces used to close the doors of automatic elevators are limited so as to prevent injury to any person who might be in the way of the doors. A pressure difference across the doors would add to the friction forces that the door closer must overcome. A sufficiently large pressure difference could cause an elevator to jam in the open position. In the early stages of this project it was felt that this door jamming problem might be so significant that it might prohibit the use of elevators as a means of fire exit. However, successful operation of elevator doors without jamming in the field tests has shown that this problem is not the concern it was originally envisioned to be. 


\section{FIELD TESTS}

Field tests were performed in six buildings with pressurized elevator shafts. These tests form a screening of some existing systems. The reader is cautioned that the systems tested should not be considered model designs for smoke control. However, some useful insight into elevator shaft pressurization can be gained from these tests. The primary purpose of all of the pressurized elevator systems was for use by the fire department for rescue and fire fighting. Only two buildings (buildings 4 and 5) had elevator lobbies separated by barriers from other building spaces.

In all of these tests the difference between the indoor and outdoor temperatures was very sma11. Also, during these tests the wind velocities were relatively calm and, accordingly, no wind data was taken. In general, the pressure fluctuations did not exceed $1.2 \mathrm{~Pa}\left(0.005\right.$ in $\left.\mathrm{H}_{2} \mathrm{O}\right)$, so only average values of pressure difference are listed in the tables. There was one exception among the field tests where the fluctuation exceeded this level; this is specifically addressed in the discussion.

In many of the elevator shaft pressurization systems tested, the pressurization was by a propeller fan. This type of fan is usually intended to move a large quantity of air against a very low pressure head ${ }^{4}$. However, when a propeller fan operates at higher pressure heads the flow rate drops dramatically. For this reason, the actual flow rates of the fans in these tests were probably much lower than the rated capacities of the fans.

\footnotetext{
${ }^{4}$ General information concerning propeller fans and other fan types is provided by ASHRAE [4].
} 


\subsection{Building 1}

The first test building is a four story office building located in Ohio. The building (shown in figure 1) has a four story elevator with two cabs which open onto an atrium. The elevator shaft was pressurized by a roof mounted propeller fan rated at $2000 \mathrm{l} / \mathrm{s}(4300 \mathrm{cfm})$ at $31 \mathrm{~Pa}\left(1 / 8\right.$ in $\left.\mathrm{H}_{2} 0\right)$ static pressure.

With all the elevator doors closed the pressurization system maintained differential pressures across the elevator shaft ${ }^{5}$ in the range of 3.0 to 5.0 $\mathrm{Pa}\left(0.012\right.$ to 0.02 in $\left.\mathrm{H}_{2} \mathrm{O}\right)$ as listed in table 1 . While the pressurization system was operating, the elevator doors opened and closed normally. In addition, because the elevators are programmed to go to the ground floor during a fire alarm, the pressurization system was also tested with the elevator cabs at ground level and an elevator door open at ground level. Under this arrangement, no pressure differential could be measured across the elevator door (however, movement of cigarette smoke indicated that there was some air flow out of the shaft).

This drop in pressurization can be explained by comparing the flow areas of closed elevator doors with that of open elevator doors. Even though flow areas were not measured for this building, in a report by Tamura and Shaw [5] measurements of this type were reported for seven buildings. They found the flow area around closed elevator doors to be in the range of 0.051 to $0.065 \mathrm{~m}^{2}$

\footnotetext{
${ }^{5}$ In this report, the phrase "differential pressure across the elevator shaft" means the pressure difference between the elevator shaft and the elevator lobby where a higher elevator shaft pressure is considered positive.
} 
$\left(0.55\right.$ to $\left.0.70 \mathrm{ft}^{2}\right)$ and that of an open elevator door with cab in place at 0.56 $\mathrm{m}^{2}\left(6.0 \mathrm{ft}^{2}\right)$. If the leakage paths for the elevator shaft tested in building 1 are in the same range, then opening an elevator door amounts to approximately doubling the total flow area from the elevator shaft to the building. This accounts for the significant decrease of shaft pressure.

\subsection{Building 2}

The second building (also located in ohio) is a motel consisting of four wings as shown in figures 2 and 3. The main lobby and front desk are located in wing $A$ which is one story high. Wings B, C, and D contain the guest rooms. Wing $C$ is four stories, and wings $B$ and $D$ are both seven stories.

Wings $\mathrm{B}, \mathrm{C}$, and $\mathrm{D}$ have pressurized stairwells, pressurized corridors, and pressurized elevator shafts. The concept behind pressurized stairwells and corridors is that pressurization can prevent smoke infiltration, thus maintaining the stairwell or corridor as a smoke free means of fire exit. Considerable information regarding pressurized stairwells is available in the literature in [6-11]. To date no literature is available on pressurized corridors.

These smoke control systems are intended to be activated only in the wing in which smoke is detected or in which sprinkler flow is detected. Automatic closing doors separate wing $C$ from the other wings when the smoke control systems in wing $\mathrm{C}$ are activated. For this reason wing $\mathrm{C}$ was studied separately. 
All of the smoke control fans for wing $C$ were roof mounted propeller fans. The corridor fan supplied air into a duct which supplied the corridors on each floor. This fan was rated at $1900 \mathrm{l} / \mathrm{s}(4000 \mathrm{cfm})$. The stairwell fans were located on top of each of the stair shafts and dumped air directly into the shaft. These fans were each rated at $1900 \mathrm{l} / \mathrm{s}(4000 \mathrm{cfm})$. The elevator fan, rated at $2300 \mathrm{l} / \mathrm{s}(4800 \mathrm{cfm})$, supplies air to the top of the elevator shaft. The elevator shaft in wing $C$ contained one cab but the shaft was sized so that another cab could be added.

\subsubsection{All Smoke Control Systems Operating}

With all three of the smoke control systems operating in wing $C$ the pressure differential across the elevator and across stairwel1 1 are listed in table 2. The elevator pressurization system maintained differential pressures in the range of 12 to $16 \mathrm{~Pa}\left(0.050\right.$ to 0.065 in $\left.\mathrm{H}_{2} \mathrm{O}\right)$ across the elevator shaft when all elevator doors were closed. Throughout the tests the elevator doors opened and closed properly. The pressures across stairwell 2 were checked and determined to be in the same range as those across stairwell 1.

The elevator pressures were much higher for the test in this building than for the test in building 1 (see table 1). Both systems are four stories and the pressurization fans were rated in the same range; $2000 \mathrm{l} / \mathrm{s}(4300 \mathrm{cfm})$ for building 1 and $2300 \mathrm{l} / \mathrm{s}(4800 \mathrm{cfm})$ for wing $\mathrm{C}$ of building 2. The major difference was that the building 1 shaft had eight elevator doors and the wing $C$ shaft only had four doors. This would suggest that the higher pressures 
across the elevator shaft in wing $C$ were due to the lower leakage area of this shaft.

As in the case of building 1 , tests were run with the elevator cab at the ground level (floor 1) and with the elevator door open. In this situation there was a pressure difference of $1.7 \mathrm{~Pa}\left(0.007\right.$ in $\left.\mathrm{H}_{2} \mathrm{O}\right)$ across the elevator shaft at the second level. A pressure drop was expected after the experience with an open elevator door in building 1 . The decreased pressure difference in both cases reduces the level of smoke protection of the pressurized elevator shaft.

The effect on the pressurized elevator shaft of opening a door to the pressurized stairwell was evaluated. As might be expected, opening a stairwell door on a particular floor reduced the level of elevator shaft pressurization on that floor. When the fourth floor stairwell door was opened the pressure difference across the fourth floor elevator shaft door dropped from 16 to $7.5 \mathrm{~Pa}\left(0.065\right.$ to 0.030 in $\left.\mathrm{H}_{2} \mathrm{O}\right)$. When the same thing was done on the first floor the pressure difference across the elevator shaft dropped from 16 to $12 \mathrm{~Pa}\left(0.065\right.$ to 0.050 in $\left.\mathrm{H}_{2} \mathrm{O}\right)$. These results demonstrate that the elevator shaft pressurization system was capable of maintaining positive pressurization with a stairwell door open and the elevator door closed. Other tests demonstrated that an open elevator door had no measurable effect on the stairwell pressurization system. 
A test was performed with only the stairwell pressurization systems and the elevator shaft pressurization system operating, in order to determine the effect of shutting off the corridor pressurization system. The pressures for this test with all elevator doors closed are listed in table 3 . It is apparent by comparing this data with that for the corridor system operating (table 2), that the corridor pressurization system generally had little effect on the performance of the elevator shaft pressurization system. The exception to this was at the first floor where without corridor pressurization the elevator shaft pressure decreased from $16 \mathrm{~Pa}$ to $10 \mathrm{~Pa}(0.065$ to 0.040 in $\mathrm{H}_{2} \mathrm{O}$ ). Due to the unknown nature of the flow paths throughout the building, it is difficult to determine the cause for this pressure drop on the first floor. It may have been due to an increase in the wind velocity or to a change in the building flow network. One possible change in the flow network could occur when a door was opened to a guest room which had an open window. The decrease could also simply reflect a new steady state flow condition for the building.

\subsubsection{Elevator Shaft Pressurization Operating}

A test was made with only the elevator shaft pressurization operating to further evaluate the interaction between the different smoke control systems. The pressures for this test with all elevator doors closed are listed in table 4. By comparing these data with the tests when all the smoke control systems were on (table 2) and when just the stairwell system was on (table 3 ), it is apparent that the operation of the other smoke control systems generally had a 
minor effect on the performance of the elevator shaft pressurization system. An exception to this is at the fourth floor where the pressure dropped by 2 or $3 \mathrm{~Pa}\left(0.007\right.$ or 0.012 in $\left.\mathrm{H}_{2} \mathrm{O}\right)$ depending on with which test it is compared. It can also be noted that the pressure across the elevator shaft at the first floor was approximately the same with all three systems on or with only the elevator shaft system on. Again, these exceptions may be due to changes in the wind, changes in the building flow network, or they may simply reflect a new steady state flow condition.

\subsubsection{Wings $B$ and $D$}

Wings $B$ and $D$ are both seven stories and are connected to each other at each floor by corridors without barriers to air or smoke movement. Automatic closing doors separated wing B from wings A and C. For these reasons wings B and $\mathrm{D}$ were tested together as one unit. The elevator shaft pressurization system was tested with the stairwell and corridor systems on. The pressures, 1isted in table 5, were measured with the stairwel1 doors and elevator doors closed. It can be observed that the differential pressures across the elevator shafts varied considerably from floor to floor. For the elevator shaft in wing $\mathrm{B}$ the pressures ranged from 2.0 to $10 . \mathrm{Pa}(0.008$ to 0.040 in $\mathrm{H}_{2} \mathrm{O}$ ). The range over which the elevator shaft in wing $\mathrm{D}$ varied was somewhat less, from 5.0 to 11 . Pa $\left(0.020\right.$ to 0.045 in $\left.\mathrm{H}_{2} \mathrm{O}\right)$.

In order to determine if these pressure differences changed with time, a number of the measurements were repeated. The new measurements agreed well with the data in table 5 except for floor 6 of the elevator in wing $B$. This had been the point of lowest pressure across the elevator at $2.0 \mathrm{~Pa}(0.008$ in 
$\mathrm{H}_{2} \mathrm{O}$ ) in the initial measurements. It was remeasured in the range from 2.5 to $-2.5 \mathrm{~Pa}\left(0.01\right.$ to -0.01 in $\left.\mathrm{H}_{2} \mathrm{O}\right)$. The negative pressure indicated the elevator shaft was at a lower pressure than the corridor. Such fluctuations between positive and negative pressure have been observed in previous field tests of pressurized stairwells [6] and were attributed to wind effects. However, the wind effects would not cause the elevator shaft pressures to vary from floor to floor to the extent discussed above.

It was thought that these variations in elevator shaft pressures might be due to a large air connection from the building to the outside at one or more floors. Wings $B$ and $D$ were checked for such connections. It was observed that a number of the guest room windows were open, but the doors from rooms to the corridor were closed. Therefore, no direct flow path from the corridors to the outside could be found. It also can be observed from figures 2 and 3 that these wings $B$ and $D$ are connected to wing $A$ at the first floor and connected to wing $\mathrm{C}$ at floors 1 through 4. These connections and the open guest room windows resulted in a complicated flow network which obviously differed considerably from floor to floor. These differences could result in variations in the pressures across the elevator shafts from floor to floor.

\subsubsection{Pressurized Stairwells}

It can be observed from table 5 that the differential pressure across the stairwell doors was uniform over the height of the stairwells. It can also be observed that the level of pressurization was considerably higher for stairwell 5 than for the other three. This happened even though each of the stairwells was supplied by propeller fans rated at $3800 \mathrm{l} / \mathrm{s}(8000 \mathrm{cfm})$. The cracks 
around the doors of stairwell 5 were small and the doors were not undercut. The doors to stairwells 3 and 4 were undercut approximately $16 \mathrm{~mm}$ (5/8 in). Based on previous studies, this increased leakage area can account for the lower pressures in stairwells 3 and 4. While the doors to stairwell 6 were as tight-fitting as those to stairwell 5, the exterior door to stairwell 6 had no latch and was held open by air pressure. When this exterior door was closed the leakage was similar to that in stairwell 5, and the pressure across stairwe11 6 was measured to be $85 \mathrm{~Pa}\left(0.34\right.$ in $\left.\mathrm{H}_{2} \mathrm{O}\right)$ at the first floor door from the stairwell to the corridor.

\subsection{Building 3}

The third building is a 20 story apartment building used for student housing in Detroit, Michigan. Floor plans for the building are shown in figures 4 and 5. There is one elevator shaft with two cabs. The elevator is pressurized from the top by a propeller fan rated to supply $8000 \ell / \mathrm{s}(17,000$ cfm) at $62 \mathrm{~Pa}\left(1 / 4\right.$ in $\left.\mathrm{H}_{2} \mathrm{O}\right)$ static pressure. Continuous corridor pressurization is obtained by a system which supplies conditioned air into the corridor on each floor. This conditioned air is supplied by a roof mounted air handling unit with a supply fan rated at $14,000 \mathrm{l} / \mathrm{s}(30,000 \mathrm{cfm})$ at $560 \mathrm{~Pa}$ (2$1 / 4$ in $\mathrm{H}_{2} \mathrm{O}$ ) static pressure. The building plans indicated that the stairwells were also pressurized by propeller fans; however, these fans were installed backwards, which would result in exhausting rather than pressurizing the stairwe $11 s^{6}$. For this reason, the stairwell fans were not operated during these tests; however, the corridor pressurization system was operating.

\footnotetext{
${ }^{6}$ Maintenance personnel at building 3 stated that arrangements were underway to correct this problem.
} 
Table 6 lists the pressures across the elevator with the elevator shaft unpressurized and pressurized. With the elevator shaft unpressurized, the upper floors of the shaft had positive pressures and the lower floors had negative pressures. This indicates that air was flowing into the shaft at the bottom and out of the shaft at the top. This flow is referred to as stack effect and frequently occurs when the building temperature is greater than the outside temperature. However, during this test the building temperature was $2^{\circ} \mathrm{C}\left(3.6^{\circ} \mathrm{F}\right)$ below the outside temperature. Obviously, other driving forces must have existed.

As might be expected, when the elevator pressurization system was on, the level of pressurization increased with building height (table 6). The elevator shaft pressurization system failed to maintain positive pressurization at the basement and first floor. Therefore, in the event of a fire on one of these levels the smoke would infiltrate the shaft, and the smoke would then be distributed by the elevator shaft throughout the building.

At a number of times during these tests a direct air connection existed from the building to the outside for a short period of time. On the first floor this resulted from opening the ground floor door. On the other floors it occurred as a result of having an open door to an apartment which also had an open balcony door to the outside. Specific data for such occurrences are listed as notes to table 6. As expected, in all cases the pressure across the elevator shaft increased at the floor with the direct air connection to the outside. 


\subsection{Building 4}

The fourth building is a 12 story apartment building for the aged in Detroit, Michigan. Figure 6 is a typical floor plan for this building. The building has one elevator shaft with two cabs. Unlike any of the other test buildings discussed in this paper, building 4 has automatic closing doors which separate the elevator lobby from other building spaces. The building was equipped with pressurization systems for the stairwells and elevator shaft and with unique smoke control capabilities for the corridors.

Both stairwells and elevator shafts have their own specially dedicated pressurization fans located at ground level. These three fans were centrifugal type rated at $440 \mathrm{l} / \mathrm{s}(930 \mathrm{cfm})$ at a static pressure of $370 \mathrm{~Pa}(1.5 \mathrm{in}$ $\mathrm{H}_{2} \mathrm{O}$ ). From experience, it was apparent that these fan capacities were too low, and therefore they would have almost no pressurizing effect for the stairwells or the elevator shaft.

The corridor smoke control consisted of a corridor supply system and two corridor exhaust systems. Conditioned air was continuously supplied to the corridors from a roof mounted air handling unit. The supply fan was a centrifugal type rated at $12,300 \mathrm{\ell} / \mathrm{s}(26,100 \mathrm{cfm})$ at $311 \mathrm{~Pa}\left(1.25\right.$ in $\left.\mathrm{H}_{2} \mathrm{O}\right)$ of static pressure. The supply air was distributed through a vertical duct which dumped air into a plenum over the elevator lobby. Air from the plenum was supplied directly to the corridors on either side of the elevator 1obby. Upon inspection of the building it was found that air from the plenum on each floor was leaking through cracks around door frames, lights and electric switches into the elevator lobby. 
The two corridor exhaust systems were designed so that they could exhaust air on the fire floor from either side of the elevator lobby. Each corridor exhaust system had a roof mounted exhaust fan rated at $2000 \mathrm{l} / \mathrm{s}$ (4300 cfm) at $93 \mathrm{~Pa}\left(3 / 8\right.$ in $\left.\mathrm{H}_{2} \mathrm{O}\right)$ of static pressure. Each exhaust fan was connected to a vertical exhaust duct (see figure 6) connected to the corridor at each floor. Behind the exhaust grilles on each floor was a normally closed damper. In the event of a fire alarm the procedure for activation of the smoke control systems entail the following events:

1. The stairwell pressurization systems are activated.

2. The elevator pressurization system is activated.

3. The roof mounted corridor exhaust fans are activated.

4. The normally closed dampers of the corridor exhaust system are opened only on the floor from which the fire alarm originated.

Events 3 and 4 above result in practically all of the capacity of the exhaust fans being concentrated on the floor where the fire alarm originated. The concept behind use of these exhaust systems was to exhaust smoke from the fire floor and to create a level of pressurization on non-fire floors to prevent vertical smoke movement within the building. A problem with exhausting air from the fire floor corridor is that the exhaust might pull smoke from an apartment into the corridor and thereby cause evacuation problems on the fire floor. An analysis of the benefits and shortcomings of corridor exhaust systems is beyond the scope of this paper. 
As stated earlier, the elevator lobbies in this building were separated from the rest of the building by automatic closing doors (see figure 6). The elevators were not intended for building evacuation, but were intended for rescue and fire fighting by the fire department. The smoke control systems were tested to determine the extent to which they provided a pressurized elevator lobby on the fire floor. A pull box on the fifth floor was pulled to activate the smoke control systems ${ }^{7}$. Differential pressures were measured at a number of locations on the fourth, fifth, and sixth floors. These pressure measurements are listed in table 7. The elevator lobby was positively pressurized with respect to the corridor at a level of $6.2 \mathrm{~Pa}\left(0.025\right.$ in $\left.\mathrm{H}_{2} 0\right)$ on the fifth floor where the corridor system was exhausting air. On the fourth floor where there was no corridor exhaust, only a slight elevator lobby pressurization of $0.75 \mathrm{~Pa}\left(0.003\right.$ in $\left.\mathrm{H}_{2} \mathrm{O}\right)$ existed. It can be observed from the data in table 7 that the elevator pressurization system could not maintain positive pressure across any of the elevator doors measured. The pressurization system for stairwell 1 performed slightly better with a positive pressure of $6.2 \mathrm{~Pa}\left(0.025\right.$ in $\left.\mathrm{H}_{2} \mathrm{O}\right)$ across the stairwell at the fifth floor. This pressure was higher than for the other floors and was due to the corridor exhaust on the fifth floor.

\subsection{Building 5}

The fifth building is a 38 story office building located in seattle, Washington. The floor plan at ground level is shown in figure 7 . Located under the ground level is a mall and below that is a parking level. There is

7 There is a problem with activating such a smoke control system from a pull box in that the box could be pulled on other than the fire floor. 
an escalator between the mall and the ground level. Figure 8 is a typical

floor plan of floors 3 through 19 which are served by the low rise elevators. Figure 9 is a typical floor plan of floors 20 through 36 which are served by the high rise elevators. The freight elevator served all floors.

A concept called the "life safety core" was used in the design of this building. A two hour fire rated partition encloses the elevators and the stairwells. This core is sprinklered and pressurized through the elevator shafts and stairwells. Automatic closing doors are located between the elevator lobby and the building (see figures 8 and 9).

Air is supplied to the elevator shafts by a $60,400 \mathrm{l} / \mathrm{s} \quad(128,000 \mathrm{cfm})$ vaneaxial fan located on the ground floor. This fan also supplies air to the bottom half of the two stairwells. The top half of the stairwells were supplied by a $3,780 \mathrm{l} / \mathrm{s}(8,000 \mathrm{cfm})$ vaneaxial fan located in the mechanical penthouse on the 37 th floor. Even though the elevator shafts have only one injection point each at ground level, the stairwells had a ducted supply system with injection points every five floors. Unfortunately there was no way to tell exactly how the air from the ground floor fan was distributed between the stairwells and the elevator shafts. In order to facilitate pressurization, the elevator shafts are not vented to the outside.

The pressurization system maintained pressure differences from the elevator shaft to the elevator lobby in the range of 22 to $45 \mathrm{~Pa}(0.09$ to 0.19 in $\mathrm{H}_{2} \mathrm{O}$ ) as listed in table 8 . The level of stairwell pressure was somewhat lower. This was done without any problems of elevator doors jamming open. The elevator doors in this building were sealed on the sides with a wipe type 
gasket in order to reduce the leakage areas around the doors. This was a surprise because it was believed that such sealing was not feasible with commercially available elevator doors.

The air flowing from the elevator shaft to the lobby resulted in a lobby pressurization relative to the building of 12 to $40 \mathrm{~Pa}\left(0.05\right.$ to 0.16 in $\left.\mathrm{H}_{2} \mathrm{O}\right)$ as listed in table 8 . It should be noted, that there was a non-powered exhaust duct connected to each elevator lobby to relieve some of the pressurization air when the lobby doors were closed. The inlet to this exhaust was fitted with a automatic modulating damper which was intended to maintain a pressure difference of $12 \mathrm{~Pa}\left(0.05\right.$ in $\left.\mathrm{H}_{2} \mathrm{O}\right)$ across a closed lobby door. On some floors, it appeared that this damper was not operating properly. However, it is apparent that this system is capable of maintaining pressurization of the elevator lobby with respect to the other building spaces as stated above.

The above tests were conducted with the elevator doors, stairwell doors and lobby doors closed. It is believed that if lobby doors were open on some floors, the pressure difference across closed lobby doors on other floors would drop. Unfortunately, the testing time in the building was limited and this could not be verified.

\subsection{Building 6}

The sixth building is a 22 story apartment building also located in Seattle, washington. The only public corridors in this building were located on the terrace and ground levels, and the $3 \mathrm{rd}, 7 \mathrm{th}, 11 \mathrm{th}, 15 \mathrm{th}$ and $19 \mathrm{th}$ floors 
as shown in figure 10 . The main entrances to each of the apartments was

located on one of these floors. The apartments were multistory with their own internal stairs.

The elevator shaft housed two cabs and was pressurized by a $8,500 \mathrm{l} / \mathrm{s}$ $(18,000 \mathrm{cfm})$ centrifugal fan which supplied air to the bottom of the shaft. Both stairwells were bottom injection systems supplied by one $4,700 \mathrm{l} / \mathrm{s}$ $(10,000 \mathrm{cfm})$ centrifugal fan each, and each stairwell had a barometric relief damper to the outside at the top of the shaft.

With the elevator pressurization system and both stairwell pressurization systems operating, the pressure from the elevator shaft to the corridor was in the range of 45 to $72 \mathrm{~Pa}\left(0.18\right.$ to 0.29 in $\left.\mathrm{H}_{2} 0\right)$ as listed in table 9. Even with these high pressure differences, there were no problems with elevator doors jamming open. These elevator doors differed from all the doors in the other buildings tested in that these doors were single leaf sliding doors and the others were double leaf sliding doors.

\section{ELEVATOR LOBBIES}

All of the elevator pressurization systems which have been reported on here were primarily intended for use by the fire service for fire fighting and to aid in rescue. The life safety core concept in building 5 was also intended for fire evacuation of the handicapped. This building has an elevator lobby which is indirectly pressurized through the elevator shaft. This or some other method of pressurizing the elevator lobby is essential to prevent smoke infiltration of the lobby while handicapped persons await evacuation. 


\subsection{Pressure Differences}

When the lobby doors are closed, an overpressure of the elevator lobby with respect to the building will prevent smoke infiltration from the building spaces into the lobby. It is appropriate to consider both minimum and maximum allowable pressure differences. The maximum pressure difference should be a value which does not result in excessive door opening forces. Clearly, a person's physical condition is a major factor in determining a reasonable door opening force for that person. Section 5-2.1.1.4.3 of the National Fire Protection Association (NFPA) Life Safety Code [12] states that the force required to open any door in a means of egress sha11 not exceed $222 \mathrm{~N}$ (50 1b). However, many smoke control designers feel that a lower value should be used, especially in occupancies which involve the elderly, children, or the handicapped. NFPA is currently evaluating proposals to reduce its maximum door opening force from $222 \mathrm{~N}(501 \mathrm{~b})$ to $133 \mathrm{~N}(301 \mathrm{~b})$.

For the sake of discussion, if the maximum door opening force is considered to be $133 \mathrm{~N}(30 \mathrm{lb})$, and the force to overcome the door closer is $27 \mathrm{~N}(6 \mathrm{lb})$, a hinged door $0.91 \times 2.13 \mathrm{~m}(36 \times 84 \mathrm{in})$ would have a maximum allowable pressure difference of $100 \mathrm{~Pa}\left(0.40\right.$ in $\left.\mathrm{H}_{2} \mathrm{O}\right)$.

The criterion for selecting a minimum allowable pressure difference across the elevator lobby is that no smoke leakage shall occur during building evacuation. In this case the smoke control system must produce sufficient pressure differences so that it is not overcome by the forces of wind or buoyancy of hot smoke. 

can be expressed as

$$
\Delta \mathrm{P}=\mathrm{K}_{\mathrm{S}}\left(\frac{1}{\mathrm{~T}_{0}}-\frac{1}{\mathrm{~T}_{\mathrm{F}}}\right) \mathrm{h}
$$

where:

$$
\begin{aligned}
& \Delta \mathrm{P}=\text { pressure difference, } \mathrm{Pa}\left(\mathrm{in} \mathrm{H}_{2} \mathrm{O}\right) \\
& \mathrm{T}_{\mathrm{O}}=\text { absolute temperature of the surroundings, }{ }^{\circ} \mathrm{K}\left({ }^{\circ} \mathrm{R}\right) \\
& \mathrm{T}_{\mathrm{F}}=\text { absolute temperature of the fire compartment, }{ }^{\circ}\left({ }^{\circ} \mathrm{R}\right) \\
& \mathrm{h}=\text { height above the neutral plane between fire compartment and } \\
& \text { surroundings, } \mathrm{m} \text { ( } \mathrm{ft}) \\
& \mathrm{K}_{\mathrm{S}}=
\end{aligned}
$$

The neutral plane is the plane of equal hydrostatic pressure between the fire compartment and its surroundings. For a fire with a fire compartment temperature of $800^{\circ} \mathrm{C}\left(1470^{\circ} \mathrm{F}\right)$, the pressure difference $1.52 \mathrm{~m}(5.0 \mathrm{ft})$ above the neutral plane is $13 \mathrm{~Pa}\left(0.052\right.$ in $\left.\mathrm{H}_{2} \mathrm{O}\right)$. Fang [13] has studied pressures caused by room fires during a series of full-scale fire tests. During these tests, the maximum pressure difference reached was $16 \mathrm{~Pa}\left(0.064\right.$ in $\left.\mathrm{H}_{2} 0\right)$ across the burn room wall at the ceiling. If the elevator lobby walls are subject to smoke of lower temperature, a lower pressure difference due to buoyancy will result. For a smoke temperature of $400^{\circ} \mathrm{C}\left(750^{\circ} \mathrm{F}\right)$, the pressure difference 
caused by smoke $1.52 \mathrm{~m}(5.0 \mathrm{ft})$ above the neutral plane would be $10 \mathrm{~Pa}(0.04$ in $\mathrm{H}_{2} \mathrm{O}$ ). Water spray from sprinklers cools smoke from a building fire and reduces the pressure differences due to buoyancy. Thus the pressure difference that could result from buoyancy is highly dependent upon the fire intensity and its proximity to the elevator lobby. However, it is apparent that pressurization of the elevator lobby to a level of 20 to $25 \mathrm{~Pa}(0.08$ to 0.10 in $\mathrm{H}_{2} \mathrm{O}$ ) would be sufficient to counter most any buoyancy pressure difference.

The pressure differences due to wind can become very large in the event of a broken window in a fire compartment. A wind of $22 \mathrm{~m} / \mathrm{s}(50 \mathrm{mph})$ can result in a pressure difference in the order of $200 \mathrm{~Pa}\left(0.80\right.$ in $\left.\mathrm{H}_{2} \mathrm{O}\right)$. Obviously if a system were designed such that it would not be overcome by such a wind pressure, then the door opening forces would be unacceptably high during times of low wind velocity.

One potential solution to the wind problem is to vent the fire floor on all four sides to relieve such pressures. For a building which is much longer than it is wide, it may be appropriate to vent the fire floor only on the two longer sides. A second possible approach is reliance upon fire sprinklers. Even though little research has been done on the subject, it is obvious that the operation of fire sprinklers reduces the chances of a window breaking in a fire compartment. A third approach is the use of a vestibule between the elevator lobby and the building in an attempt to provide additional protection against the forces of the wind. Further research is needed with respect to wind and methods to minimize wind effects on pressurized elevator systems. 


\subsection{Open Doors}

It is accepted that when a door in a boundary of a smoke control system is open, smoke may flow through the open door into the space which is intended to be protected. However, the door of an elevator lobby intended for evacuation of the handicapped is a very special case. Due to the basic instinct for self preservation, people inside the elevator lobby will not do nothing while smoke flows into the lobby through an open doorway. Obviously, the lobby occupants will see to it that lobby doors are only open for the short periods of time needed for other people to take refuge inside the lobby. Thus smoke infiltration of the elevator lobby will be kept to a minimum provided that positive lobby pressurization is maintained. Small quantities of smoke that do infiltrate when a door is momentarily opened will be purged by the lobby pressurization air. This approach eliminates the need to consider a design air flow through open elevator lobby doorways to prevent smoke infiltration of the lobby.

\section{HORIZONTAL PRESSURE PROFILES}

Consider an elevator protection system where the elevator lobby is pressurized indirectly by air leakage from the elevator shaft. The flow from the elevator shaft to the lobby can be expressed as

$$
Q_{E L}=A_{E L} K_{f} \sqrt{\Delta P_{E L}}
$$

where: 


$$
\begin{aligned}
Q_{E L}= & \text { volumetric air flow rate from the elevator shaft to the lobby, } \\
& \mathrm{m}^{3} / \mathrm{s}(\mathrm{cfm})
\end{aligned}
$$

$A_{E L}=$ flow area between the elevator shaft and the lobby, $m^{2}\left(f t^{2}\right)$

$\Delta \mathrm{P}_{\mathrm{EL}}=$ pressure difference between the elevator shaft and the lobby, $\mathrm{Pa}$ (in $\mathrm{H}_{2} \mathrm{O}$ )

$$
\mathrm{K}_{\mathrm{f}}=\text { constant, } 0.839(2610)
$$

The flow from the lobby to the building can be expressed as

$$
\mathrm{Q}_{\mathrm{LB}}=\mathrm{A}_{\mathrm{LB}} \mathrm{K}_{\mathrm{f}} \sqrt{\Delta \mathrm{P}_{\mathrm{LB}}}
$$

where:

$$
\begin{aligned}
& \mathrm{Q}_{\mathrm{LB}}=\text { volumetric air flow rate from the lobby to the building, } \mathrm{m}^{3} / \mathrm{s} \\
& (\mathrm{cfm}) \\
& \mathrm{A}_{\mathrm{LB}}=\text { flow area between lobby and buildings, } \mathrm{m}^{2}\left(\mathrm{ft}^{2}\right) \\
& \mathrm{PP}_{\mathrm{LB}}=\text { pressure difference between the lobby and the building, Pa (in } \\
& \left.\quad \mathrm{H}_{2} \mathrm{O}\right)
\end{aligned}
$$

With a system where no air is supplied or exhausted directly to or from the elevator lobby, and neglecting any small changes in air density, the flow from the elevator shaft to the lobby equals the flow from the lobby to the building. 


$$
Q_{E L}=Q_{L B}
$$

The pressure difference from the elevator shaft to the building equals the sum of the pressure differences from the shaft to the lobby and from the lobby to the building.

$$
\Delta \mathrm{P}_{\mathrm{EB}}=\Delta \mathrm{P}_{\mathrm{EL}}+\Delta \mathrm{P}_{\mathrm{LB}}
$$

Substituting eq. (2) and (3) into eq. (4), rearranging and cancelling $k_{f}$ yields

$$
\frac{\Delta \mathrm{P}_{\mathrm{EL}}}{\Delta \mathrm{P}_{\mathrm{LB}}}=\left(\frac{\mathrm{A}_{\mathrm{LB}}}{\mathrm{A}_{\mathrm{EL}}}\right)^{2}
$$

Dividing eq. (5) by $\Delta \mathrm{P}_{\mathrm{LB}}$ and substituting eq. (6) and rearranging yields

$$
\frac{\Delta \mathrm{P}_{\mathrm{LB}}}{\Delta \mathrm{P}_{\mathrm{EB}}}=\frac{1}{1+\left(\frac{\mathrm{A}_{\mathrm{LB}}}{\mathrm{A}_{\mathrm{EL}}}\right)^{2}}
$$

It can be observed from these two equations that their pressure differences are functions of the areas $A_{L B}$ and $A_{E L}$. Equation (7) is illustrated graphically in figure 1l. For a lobby leakage area half that of the elevator shaft leakage, the pressure difference, $\Delta \mathrm{P}_{\mathrm{LB}}$, from the lobby to the building is $80 \%$ of the total pressure difference, $\triangle \mathrm{P}_{E B}$, from the elevator to the building. Obviously, arbitrary design values of $\Delta \mathrm{P}_{\mathrm{LB}}$ and $\Delta \mathrm{P}_{\mathrm{EB}}$ cannot be selected without regard to leakage areas, $A_{L B}$ and $A_{E L}$. 
When the pressure in an elevator shaft and outside can be considered hydrostatic, the pressure difference from the shaft to the outside can be expressed as

$$
\Delta \mathrm{P}_{E O}=\Delta \mathrm{P}_{E O b}+\mathrm{K}_{\mathrm{s}}\left(\frac{1}{\mathrm{~T}_{O}}-\frac{1}{\mathrm{~T}_{E}}\right) \mathrm{y}
$$

where

$$
\begin{aligned}
{ }_{\mathrm{EO}} \mathrm{P} & \text { pressure difference from the elevator shaft to the outside at } \\
& \text { height } \left.\mathrm{y} \text { above the elevator shaft bottom, } \mathrm{Pa} \text { (in } \mathrm{H}_{2} \mathrm{O}\right) \\
\mathrm{P}_{\mathrm{EOb}}= & \text { pressure difference from the elevator shaft to the outside at the } \\
& \text { elevator shaft bottom, Pa (in } \left.\mathrm{H}_{2} \mathrm{O}\right) \\
\mathrm{T}_{\mathrm{O}}= & \text { absolute temperature of outside air, }{ }^{\circ} \mathrm{K}\left({ }^{\circ} \mathrm{R}\right) \\
\mathrm{T}_{\mathrm{E}}= & \text { absolute temperature of air inside the elevator shaft, }{ }^{\circ} \mathrm{K}\left({ }^{\circ} \mathrm{R}\right) \\
\mathrm{K}_{\mathrm{S}}= & \text { coefficient, } 3460 \text { ( } 7.64 \text { ) }
\end{aligned}
$$

Equation (8) is valid when the wind velocity and the pressure loss in the shaft due to friction are negligible. This relation gives the pressure difference from the shaft to the outside as illustrated in figure 12 for 
winter conditions (i.e., $\mathrm{T}_{\mathrm{O}}<\mathrm{T}_{\mathrm{S}}$ ). For tall buildings when the outside temperature is cold, the pressure difference, $\Delta \mathrm{P}_{E O}$, is much greater at the top of the shaft than it is at the bottom. During summer conditions (i.e., $\mathrm{T}_{\mathrm{s}}<$ $\mathrm{T}_{0}$ ), the opposite case is true.

In the case of a pressurized elevator shaft, the pressure difference, $\Delta \mathrm{P}_{\mathrm{EL}}$, between the elevator shaft and the lobby and the pressure difference, $\Delta \mathrm{P}_{\mathrm{LB}}$, between the lobby and the building are of particular interest. These pressure differences are dependent on the building flow network, including particular values of flow areas, and are also dependent on whatever other smoke control systems there are in the building. Because ${ }_{\mathrm{E}}^{\mathrm{P}}{ }_{\mathrm{O}}$ varies considerably according to eq. (8), it can be expected that $\Delta \mathrm{P}_{\mathrm{EL}}$ and $\Delta \mathrm{P}_{\mathrm{LB}}$ will also vary considerably with height. This means that at any one time the system will be producing a range of pressure differences. It is our concern that these all be within the range of allowable minimum and maximum pressure differences as discussed in section 5.1. This concern is obviously more acute for tall buildings, especially ones located where extreme outside temperatures can exist in either summer or winter.

For a few simple cases, straightforward equations for these pressure differences can be developed. However, for most realistic cases (i.e., buildings with zone smoke control systems or with vertical leakage through floor and shafts), straightforward solutions for $\Delta \mathrm{P}_{\mathrm{EL}}$ and $\Delta \mathrm{P}_{\mathrm{LB}}$ are not readily apparent. To the extent that the building flow paths are known, such cases can be analyzed with the aid of a digital computer and a computer program such as the NBS program for analysis of smoke control systems [14]. 


\section{CONCLUSIONS}

1. The potential problem of elevator doors jamming open was not observed in any of the field tests, even for pressure differences as high as $72 \mathrm{~Pa}\left(0.29\right.$ in $\left.\mathrm{H}_{2} 0\right)$ which occurred in building 6 . Therefore, the door jamming problem is not the major concern that it was envisioned to be in the early stages of this project.

2. For a pressurized elevator shaft, the increase in total flow area resulting from opening an elevator door can significantly reduce shaft pressurization levels below those when all elevator doors are closed. Field tests on building 1 and the elevator shaft in wing $C$ of building 2 illustrate this. Obviously, such a decrease in pressurization can reduce the level of smoke protection of the system.

3. Sealing elevator doors on the sides to reduce the leakage area is feasible as was observed at building 5 .

4. Elevator lobbies which are separated from other spaces on the floor by closed doors can be pressurized indirectly by supplying pressurization air into the elevator shaft as was done in building 5 . Obviously, considerations (see section 3) beyond smoke control must be addressed in order to use elevators for building evacuation. In addition, a system with air supplied through the elevator shaft may have the drawback of loss of lobby pressurization when lobby doors on other floors are open. 
5. Consideration of d design air flow through open elevator lobby

doorways to prevent smoke infiltration of the lobby is not

necessary. This is because lobby occupants, acting out of self

preservation, will keep lobby doors closed to prevent smoke infiltration ( see section 5.2 ).

6. For systems that are supplied pressurization air through the elevator shaft only, arbitrary design values of the pressure differences across the elevator shaft and across closed lobby doors cannot be selected. These pressure differences are related to each other as a function of leakage areas (see section 6).

7. Insufficient information exists at this time to design elevator pressurization systems to withstand the forces of wind (see section $5.1)$

9. FUTURE DIRECTION

All of the testing done so far in this project has consisted of pressure measurements in existing buildings with systems intended to protect elevators. Even though these tests are valuable, they do not provide a basis for prediction of how such systems will react to real fires. For this reason, tests to evaluate the performance of simulated elevator protection systems during fire conditions are needed. During such a test series the effects on these systems of parameters such as open doors and windows should be evaluated. 


\section{ACKNOWLEDGMENTS}

Thanks are due to the Beachwood Ohio Fire Department, the Seattle Fire Department, and the Detroit Michigan Building and Safety Department for their cooperation. In particular, appreciation is extended to Chief Leonard Billings of Beachwood, James J. Tracy III of Seattle, Samuel Schugar of Detroit, and Robert Taylor of Republic Steel Corp. for their aid in locating suitable test buildings and for their help during testing. Special appreciation is expressed to William A. Schmidt of the Veterans Administration and to his son and daughter, William A. Schmidt, Jr. and Karen J. Schmidt, for their considerable help during testing.

\section{REFERENCES}

[1] Klote, J. H., Elevators as a Means of Fire Escape, Nat. Bur. Stand. (U.S.), NBSIK 82-2507, May 1982.

[2] Code for Safety to Life from Fire in Buildings and Structures, NFPA 1011976, National Fire Protection Association, Inc., Quincy, MA, 1976, pp. 222 .

[3] American National Standard for Elevators, Dumbwaiters, Escalators and Moving Walks, ANSI Al7.1, American Society of Mechanical Engineers, New York, 1978.

[4] ASHRAE Handbook and Product Directory - 1979 Equipment, American Society of Heating, Refrigerating, and Air Conditioning Engineers, New York, NY, 1979.

[5] Tamura, G. T. and Shaw, C. Y., Air Leakage Data for the Design of Elevator and Stair Shaft Pressurization Systems, ASHRAE Transactions 1976, Vo1. 82, Part 2, pp. 179-190, 1976.

[6] Klote, J. H., Stairwell Pressurization, ASHRAE Transactions 1980, Vol. 86, Part 1, American Society of Heating, Refrigerating and Air Conditioning Engineers, New York, NY, 1980.

[7] DeCicco, P. R., Cresci, R. J., Correale, W. H., Report of Fire Tests, Analysis, and Evaluation of Stair Pressurization and Exhaust in HighRise Office Buildings, performed for the City of New York by the Polytechnic Institute of Brooklyn, Baywood Publishing Co., New York, NY, Sept. 1972. 
[8] Klote, J. H., Smoke Control by Stairwell Pressurization, Engineering Applications of Fire Technology Workshop, Society of Fire Protection Engineers, Boston, MA, to be published.

[9] Hedsten, G. C., Building and Stair Pressurization System, ASHRAE Journa1, Vo1. 20, No. 7, July 1978, pp. 32-35.

[10] denOuden, L., The Effect of Opening and Closing of Doors on the Pressure Levels in a Building in which the Stairwell is Pressurized, CIB Symposium on the Control of Smoke Movement in Building Fires, Vo1. II, Wat ford United Kingdom, Nov. 1975, pp. 42-49.

[11] Dias, C., Stairwe11 Pressurization in a High Rise Building, ASHRAE Journa1, Vol. 20, No. 7, July 1978, pp. 24-26.

[12] Code for Safety to Life from Fire in Buildings and Structures, NFPA 1011981, Quincy, MA, National Fire Protection Association, 1981.

[13] Fang, J. B., Static Pressures Produced by Room Fires, Nat. Bur. Stand. (U.S.), NBSIR 80-1984, Feb. 1980 .

[14] Klote, J. H., A Computer Program for Analysis of Smoke Control Systems, Nat. Bur. Stand. (U.S.), NBSIR 82-2512, June 1982. 
Table 1. Pressure Across Elevator Doors of Building 1 (all elevator doors closed)

\begin{tabular}{clc}
\hline Floor & $\begin{array}{c}\text { Differential Pressure } \\
(\mathrm{Pa})\end{array}$ & 0.012 \\
\hline 3 & 3.0 & 0.015 \\
2 & 3.8 & 0.015 \\
Ground & 3.8 & 0.020 \\
Indoor temperature $-24^{\circ} \mathrm{C}\left(75^{\circ} \mathrm{F}\right)$ & 5.0 & \\
Outdoor temperature $-26^{\circ} \mathrm{C}\left(78^{\circ} \mathrm{F}\right)$ & & \\
\hline
\end{tabular}


Table 2. Pressures in Wing $C$ of Building 2 with All Smoke Control Systems Operating

\begin{tabular}{|c|c|c|c|c|}
\hline Floor & \multicolumn{2}{|c|}{ Elevator } & \multicolumn{2}{|c|}{ Staf rwell 1} \\
\hline 4 & $16^{a}$ & $0.065^{a}$ & 67 & 0.27 \\
\hline 3 & 16 & 0.065 & 72 & 0.29 \\
\hline 2 & 12 & 0.050 & 62 & 0.25 \\
\hline 1 & $16^{\mathrm{b}}$ & $0.065^{b}$ & 67 & 0.27 \\
\hline \multicolumn{5}{|c|}{ Indoor temperature $-25^{\circ} \mathrm{C}\left(77^{\circ} \mathrm{F}\right)$} \\
\hline Outdoor te & $23^{\circ} \mathrm{C}$ & & & \\
\hline
\end{tabular}

When the fourth floor stairwell door was opened the pressure difference across the elevator shaft dropped to $7.5 \mathrm{~Pa}\left(0.030\right.$ in $\left.\mathrm{H}_{2} \mathrm{O}\right)$.

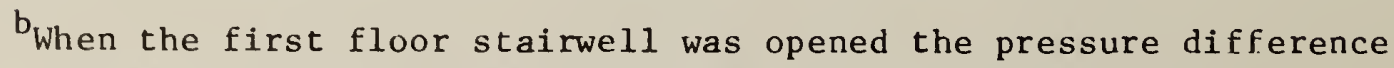
across the elevator shaft dropped to $12 \mathrm{~Pa}\left(0.050\right.$ in $\left.\mathrm{H}_{2} \mathrm{O}\right)$. 
Table 3. Pressures in Wing $C$ of Building 2 with the Corridor Pressurization System Not Operating

\begin{tabular}{|c|c|c|c|c|}
\hline \multirow[b]{2}{*}{ Floor } & \multicolumn{2}{|c|}{ Elevator } & \multicolumn{2}{|c|}{ Stairwel1 l } \\
\hline & $(\mathrm{Pa})$ & $\left(\right.$ in $\left.\mathrm{H}_{2} \mathrm{O}\right)$ & $(\mathrm{Pa})$ & (in $\mathrm{H}_{2} \mathrm{O}$ ) \\
\hline 4 & 15 & 0.060 & 67 & 0.27 \\
\hline 3 & 16 & 0.065 & 65 & 0.26 \\
\hline 2 & 14 & 0.055 & 72 & 0.29 \\
\hline 1 & 10 & 0.040 & 67 & 0.27 \\
\hline \multicolumn{5}{|c|}{ Indoor temperature $-25^{\circ} \mathrm{C}\left(77^{\circ} \mathrm{F}\right)$} \\
\hline \multicolumn{5}{|c|}{ Outdoor temperature $-23^{\circ} \mathrm{C}\left(74^{\circ} \mathrm{F}\right)$} \\
\hline
\end{tabular}


Table 4. Pressures in Wing $C$ of Building 2 with Only the Elevator Shaft Pressurization

\begin{tabular}{ccccc}
\hline Floor & $(\mathrm{Pa})$ & $\begin{array}{c}\text { Elevator } \\
\left(\mathrm{in} \mathrm{H}_{2} \mathrm{O}\right)\end{array}$ & $(\mathrm{Pa})$ & Stairwell 1 \\
$\left(\mathrm{in} \mathrm{H}_{2} \mathrm{O}\right)$
\end{tabular}

Indoor temperature $-25^{\circ} \mathrm{C}\left(77^{\circ} \mathrm{F}\right)$

Outdoor temperature $-23^{\circ} \mathrm{C}\left(74^{\circ} \mathrm{F}\right)$

Negative pressures represent air flow from building into the shaft. 


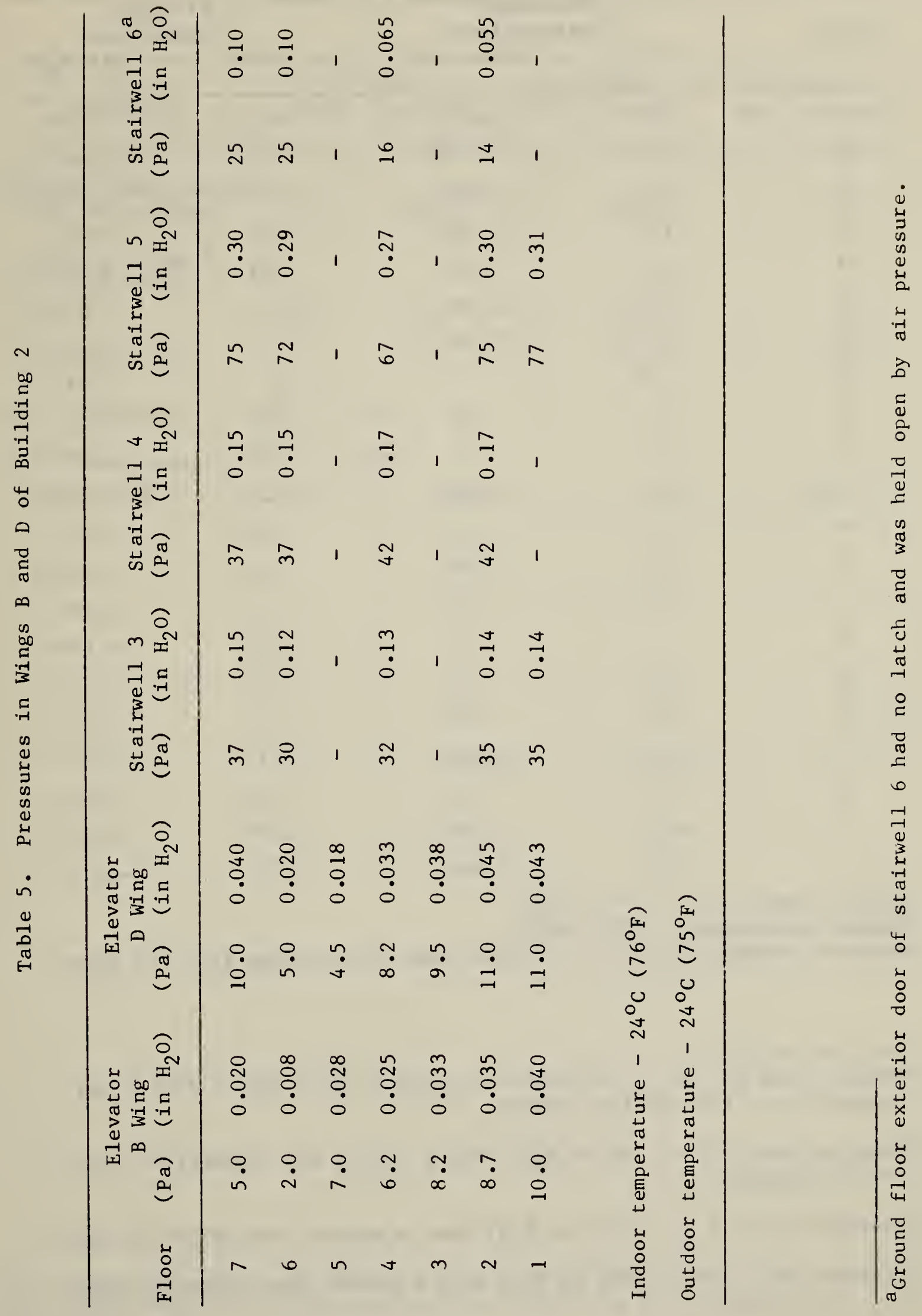


Table 6. Pressures in Building 3

\begin{tabular}{|c|c|c|c|c|}
\hline \multirow[t]{2}{*}{ Floor } & \multicolumn{2}{|c|}{$\begin{array}{c}\text { Elevator } \\
\text { Unpressurized }\end{array}$} & \multicolumn{2}{|c|}{$\begin{array}{c}\text { Elevator } \\
\text { Pressurized }\end{array}$} \\
\hline & $(\mathrm{Pa})$ & $\left(\right.$ in $\left.\mathrm{H}_{2} \mathrm{O}\right)$ & $(\mathrm{Pa})$ & $\left(\right.$ in $\left.\mathrm{H}_{2} \mathrm{O}\right)$ \\
\hline 21 & 2.5 & 0.010 & 8.7 & 0.035 \\
\hline 20 & $2 \cdot 5^{a}$ & $0.010^{a}$ & 7.5 & 0.030 \\
\hline 19 & 0.75 & 0.003 & $6.2^{b}$ & $0.025^{b}$ \\
\hline 18 & $1.2^{a}$ & $0.005^{a}$ & 5.5 & 0.022 \\
\hline 17 & 0.75 & 0.003 & 4.0 & 0.016 \\
\hline 16 & 0.75 & 0.003 & 3.2 & 0.013 \\
\hline 15 & 0.75 & 0.003 & 3.0 & 0.012 \\
\hline 14 & +0 & +0 & 2.7 & 0.011 \\
\hline 12 & +0 & +0 & 2.5 & 0.010 \\
\hline 11 & 0 & 0 & 2.0 & 0.008 \\
\hline 10 & 1.2 & 0.005 & 5.0 & 0.020 \\
\hline 9 & 0 & 0 & 3.0 & 0.012 \\
\hline 8 & 1.2 & 0.005 & 5.0 & 0.020 \\
\hline 7 & 0 & 0 & 1.5 & 0.006 \\
\hline 6 & 0 & 0 & 2.2 & 0.009 \\
\hline 5 & -0 & -0 & 1.2 & 0.005 \\
\hline 4 & +0 & +0 & 1.2 & 0.005 \\
\hline 3 & -0.75 & -0.003 & 3.7 & 0.015 \\
\hline 2 & -0 & -0 & 1.2 & 0.005 \\
\hline 1 & $-8.7^{c}$ & $-0.035^{c}$ & $-4 \cdot 0^{d}$ & $-0.016^{d}$ \\
\hline B & -6.2 & -0.025 & -2.0 & -0.008 \\
\hline
\end{tabular}

a Pressure was 8.7 to $10 \mathrm{~Pa}\left(0.035\right.$ to 0.040 in $\left.\mathrm{H}_{2} 0\right)$ when a direct air connection to the outside existed.

${ }^{\mathrm{b}}$ Pressure was $22 \mathrm{~Pa}\left(0.09\right.$ in $\left.\mathrm{H}_{2} \mathrm{O}\right)$ when a direct air connection to the outside existed.

${ }^{c}$ Pressure was $2.5 \mathrm{~Pa}\left(0.010\right.$ in $\left.\mathrm{H}_{2} \mathrm{O}\right)$ when a ground floor door was open.

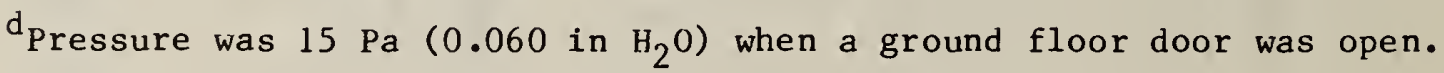


Table 7. Pressures in Building 4

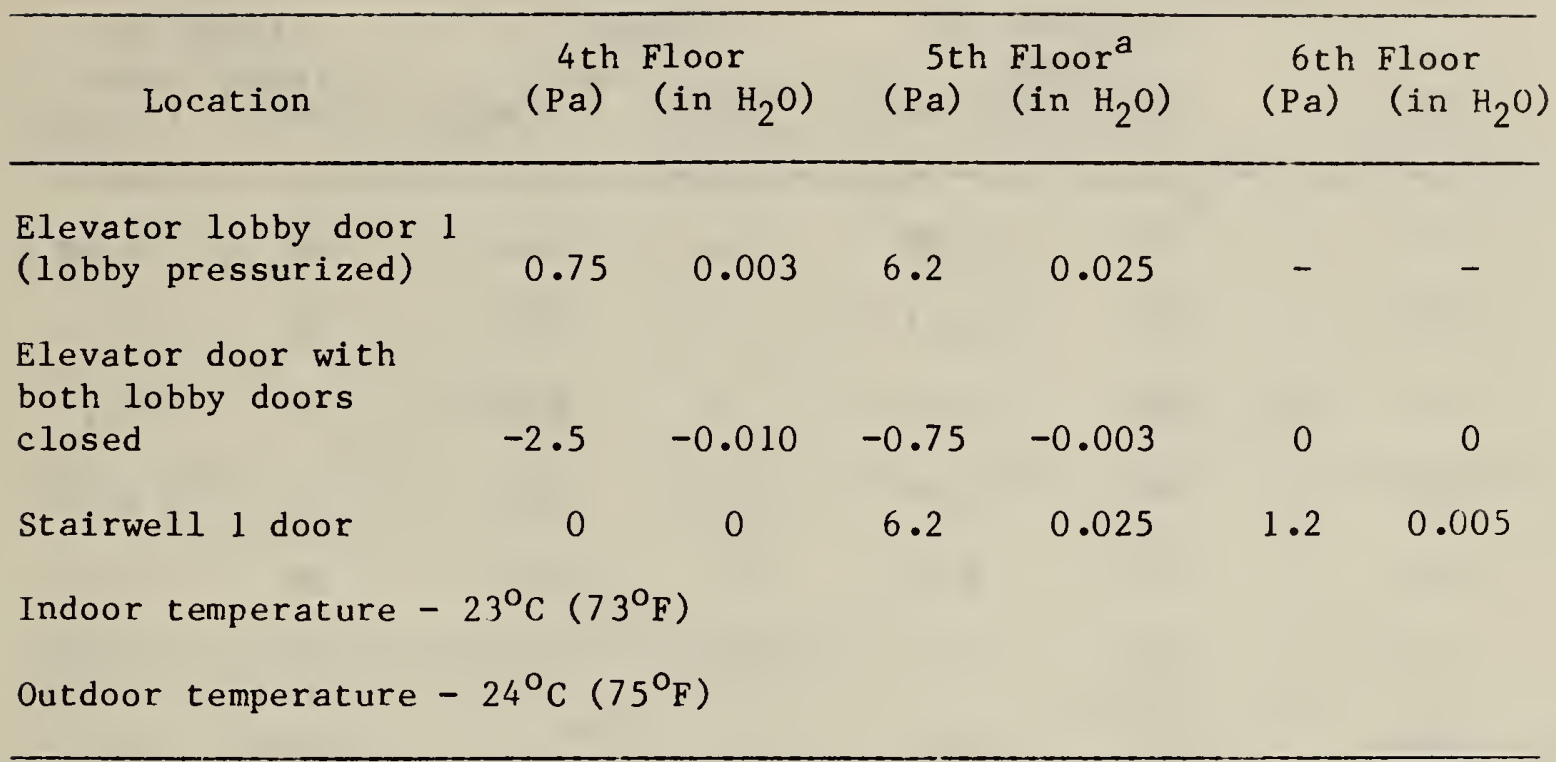

\footnotetext{
${ }^{a}$ Fire alarm sent from fifth floor so that corridors are exhausted on this floor only.
} 
Table 8. Pressure Differences from Building 5

\begin{tabular}{|c|c|c|c|c|c|c|}
\hline \multirow[b]{2}{*}{ Floor } & \multicolumn{2}{|c|}{$\begin{array}{c}\text { Elevator to } \\
\text { lobby }\end{array}$} & \multicolumn{2}{|c|}{$\begin{array}{c}\text { Stairwell } 2 \\
\text { to lobby }\end{array}$} & \multicolumn{2}{|c|}{$\begin{array}{l}\text { Lobby to } \\
\text { rental space }\end{array}$} \\
\hline & $(\mathrm{Pa})$ & $\left(\right.$ in $\left.\mathrm{H}_{2} \mathrm{O}\right)$ & $(\mathrm{Pa})$ & $\left(\mathrm{in} \mathrm{H}_{2} \mathrm{O}\right)$ & $(\mathrm{Pa})$ & $\left(\mathrm{in} \mathrm{H}_{2} \mathrm{O}\right)$ \\
\hline 36 & 22 & 0.09 & 12 & 0.05 & 40 & 0.16 \\
\hline 30 & 27 & 0.11 & 5 & 0.02 & 30 & 0.12 \\
\hline 21 & 25 & 0.10 & 12 & 0.05 & 27 & 0.11 \\
\hline 20 & 45 & 0.18 & 25 & 0.10 & 12 & 0.05 \\
\hline 10 & 25 & 0.10 & 12 & 0.05 & 25 & 0.10 \\
\hline 3 & 30) & 0.12 & 12 & 0.05 & 12 & 0.05 \\
\hline main lobby & 27 & 0.11 & -- & - & -- & -- \\
\hline
\end{tabular}

Average building temperature $25^{\circ} \mathrm{C}\left(77^{\circ} \mathrm{F}\right)$

Outside temperature $17^{\circ} \mathrm{C}\left(63^{\circ} \mathrm{F}\right)$ at start of test and $21^{\circ} \mathrm{C}\left(70^{\circ} \mathrm{F}\right)$ at end of test 
Table 9. Pressure Differences from Building 6

\begin{tabular}{|c|c|c|c|c|c|c|c|c|c|}
\hline \multicolumn{2}{|r|}{ Floor } & \multicolumn{2}{|c|}{$\begin{array}{l}\text { Elevator to } \\
\text { Corridor }\end{array}$} & \multicolumn{2}{|c|}{$\begin{array}{l}\text { Corridor to } \\
\text { Apartment }\end{array}$} & $\begin{array}{r}\mathrm{Nc} \\
\text { Stai } \\
\text { to Cc } \\
(\mathrm{Pa})\end{array}$ & $\begin{array}{l}\text { rth } \\
\text { rwell } \\
\text { rridor } \\
\left(\text { in } \mathrm{H}_{2} \text { ) }\right.\end{array}$ & $\begin{array}{r}\text { So } \\
\text { St a } \\
\text { to C } \\
(\mathrm{Pa})\end{array}$ & $\begin{array}{l}\text { uth } \\
\text { rwell } \\
\text { rridor } \\
\left(\text { in } \mathrm{H}_{2} \mathrm{O}\right)\end{array}$ \\
\hline & 19 & 72 & 0.29 & 30 & 0.12 & 72 & 0.29 & 75 & 0.30 \\
\hline & 11 & 45 & 0.18 & 10 & 0.04 & 105 & 0.42 & 100 & 0.40 \\
\hline main & lobby & 55 & $0.22^{a}$ & 35 & $0.14^{a}$ & 77 & $0.31^{a}$ & 122 & $0.49^{b}$ \\
\hline \multicolumn{10}{|c|}{ Average building temperature $25^{\circ} \mathrm{C}\left(77^{\circ} \mathrm{F}\right)$} \\
\hline \multicolumn{10}{|c|}{ Outside temperature $19^{\circ} \mathrm{C}\left(66^{\circ} \mathrm{F}\right)$} \\
\hline
\end{tabular}

apressure differences taken with ground floor exterior lobby door open.

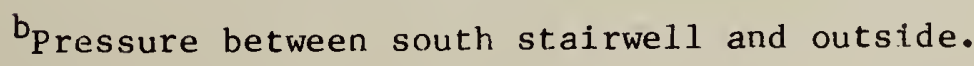



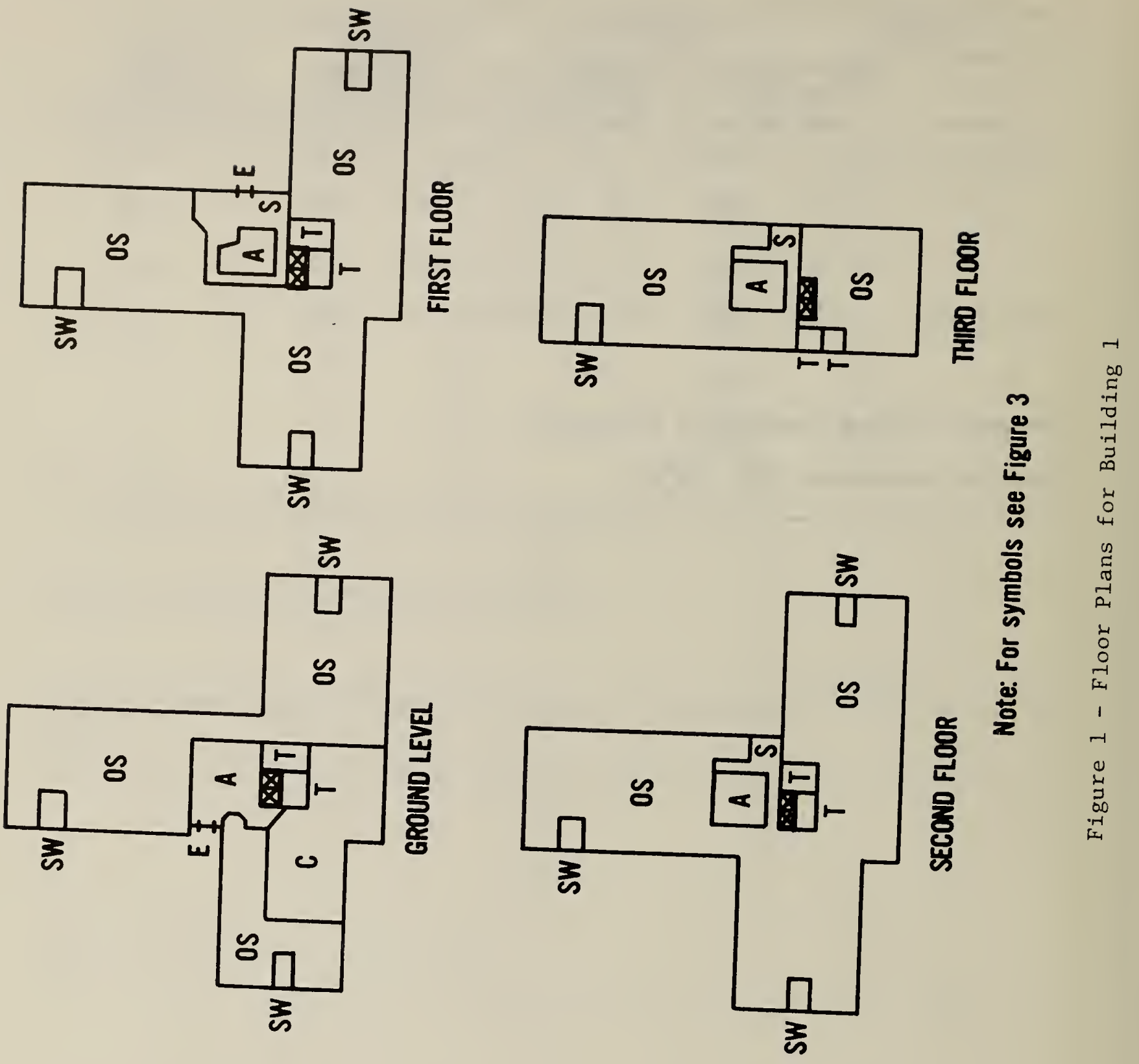


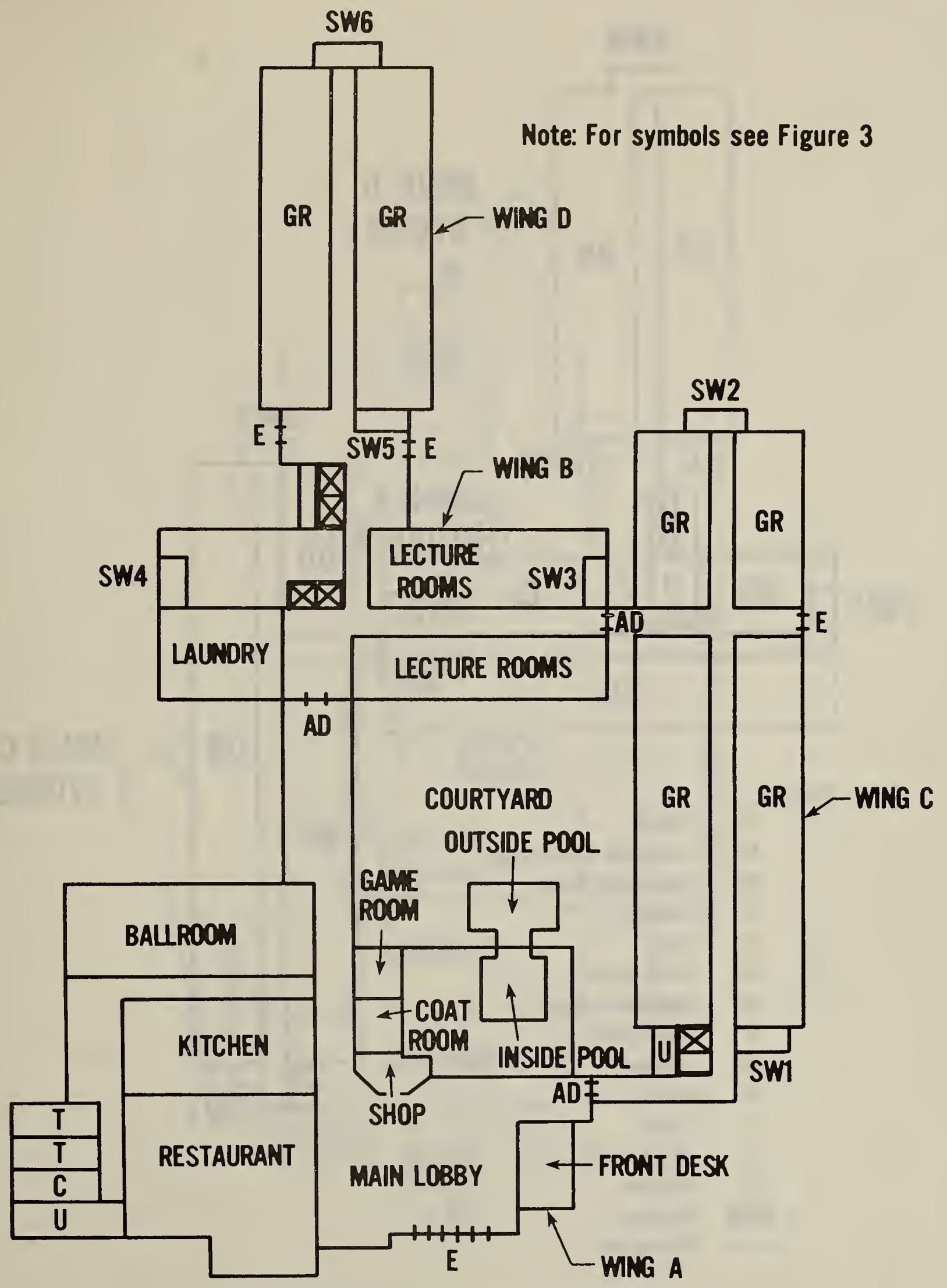

\footnotetext{
Figure 2 - Floor Plan for First Floor for Building 2
} 


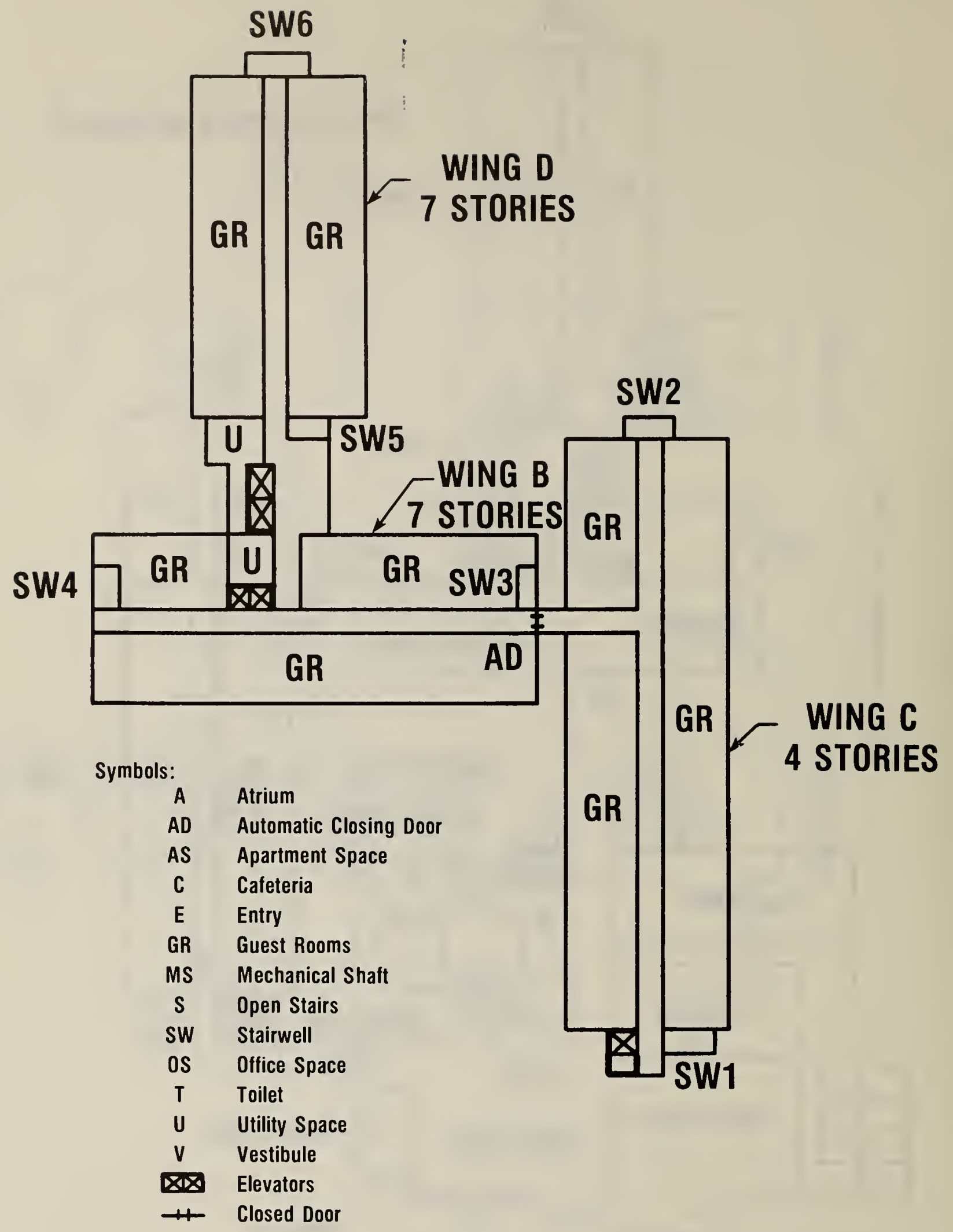

Figure 3 - Typical Floor Plan above the First Floor for Building 2 


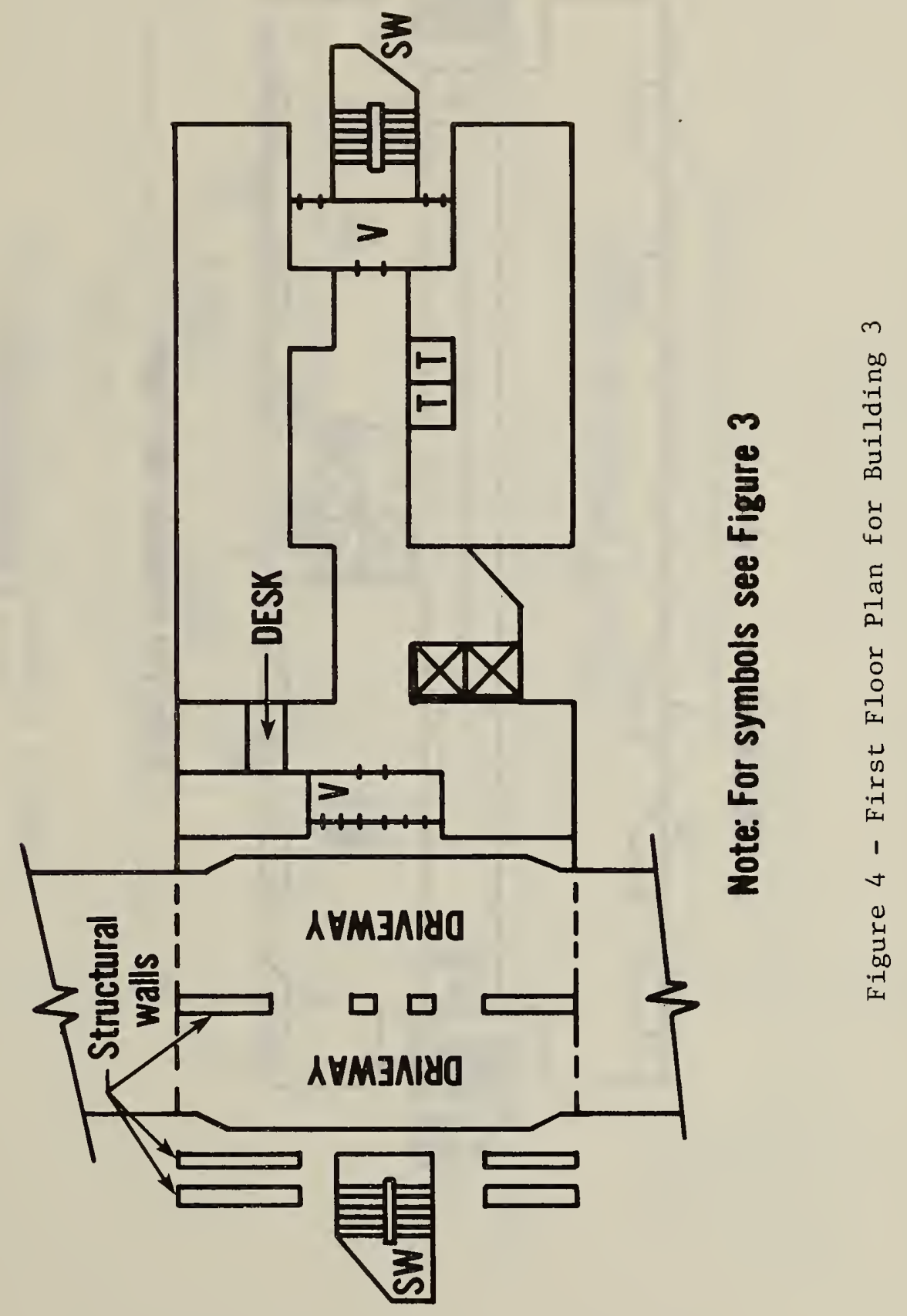




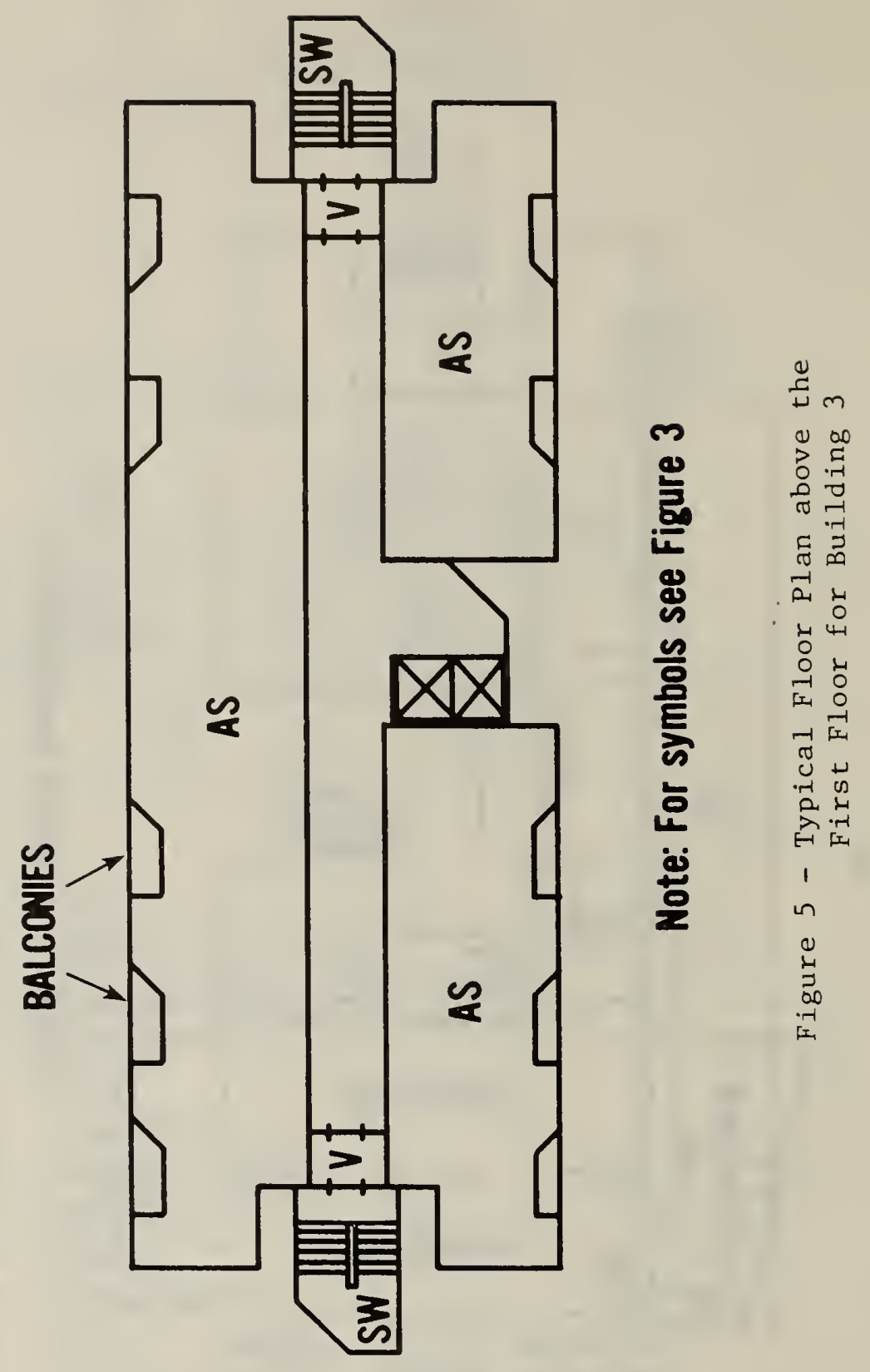




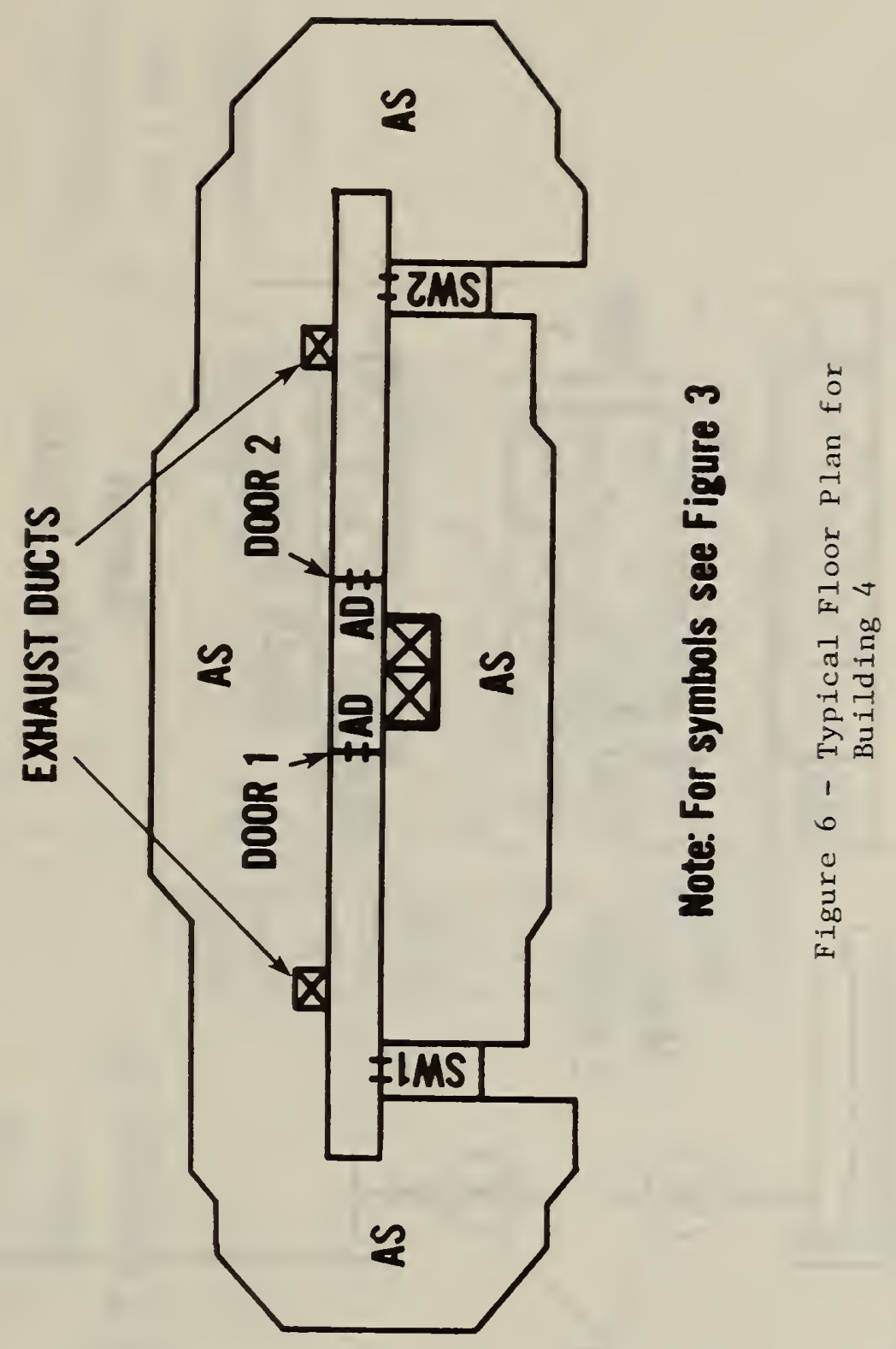




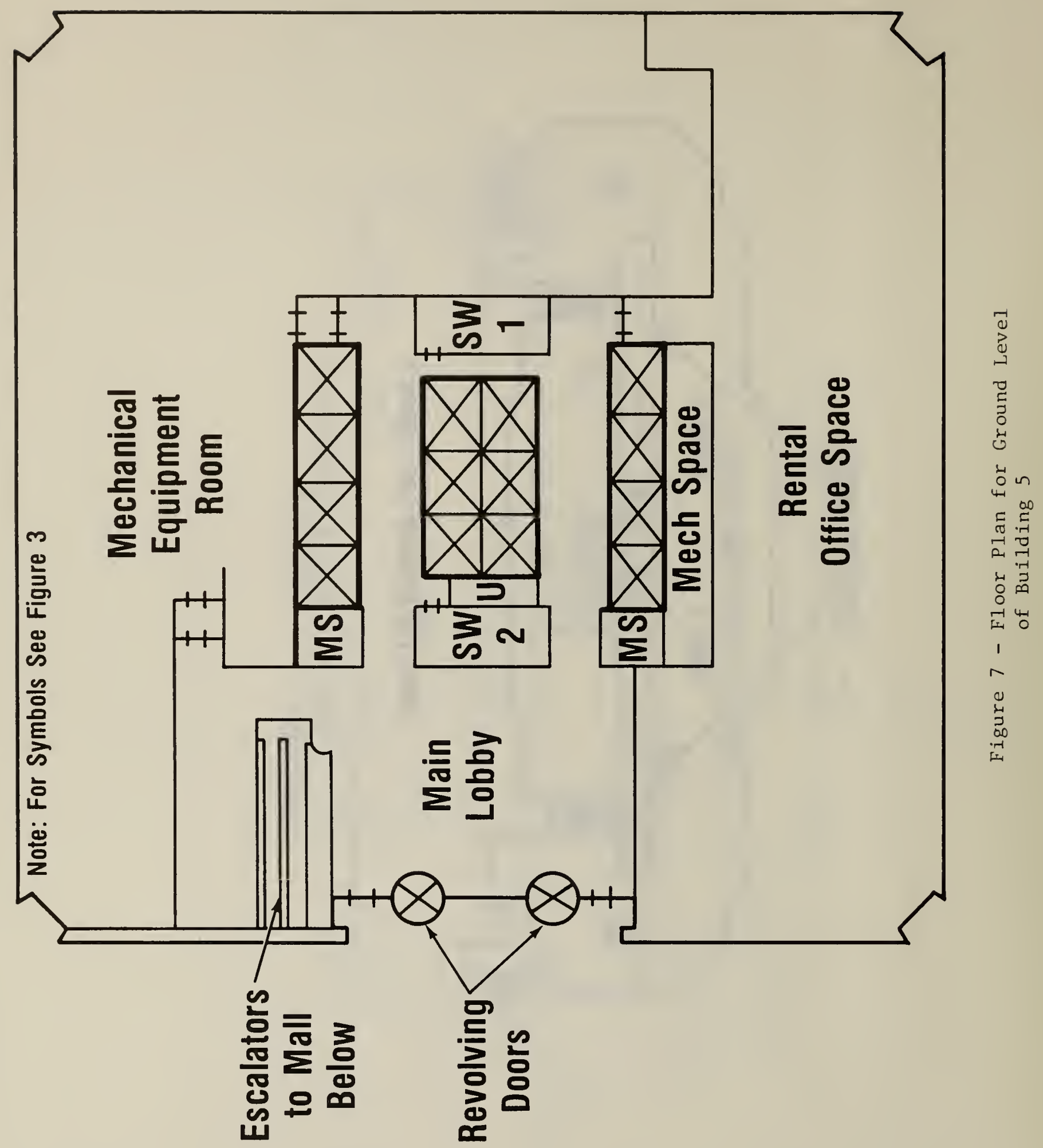




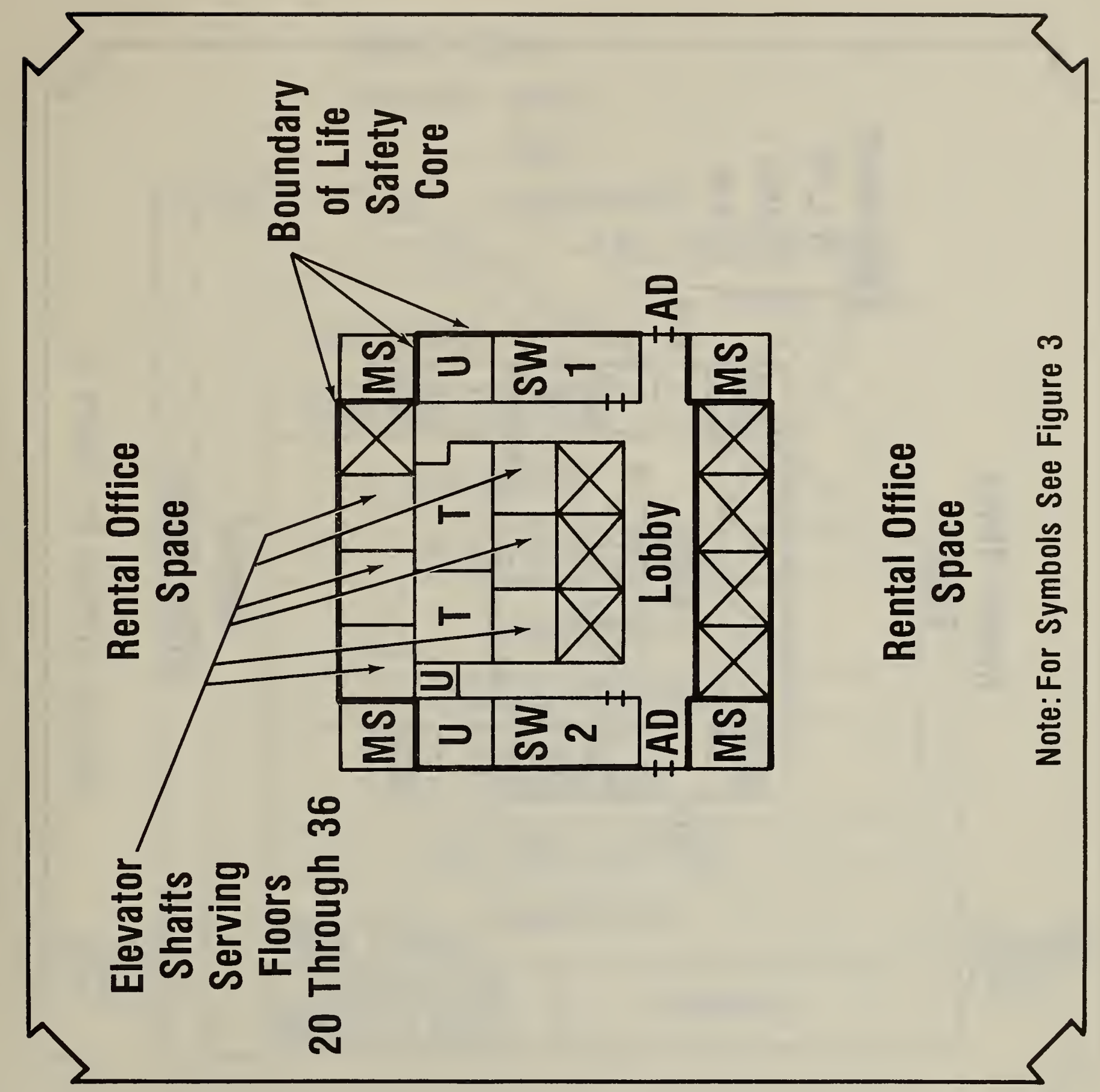

Figure 8 - Typical Floor Plan for Floors

3 through 19 of Building 5 


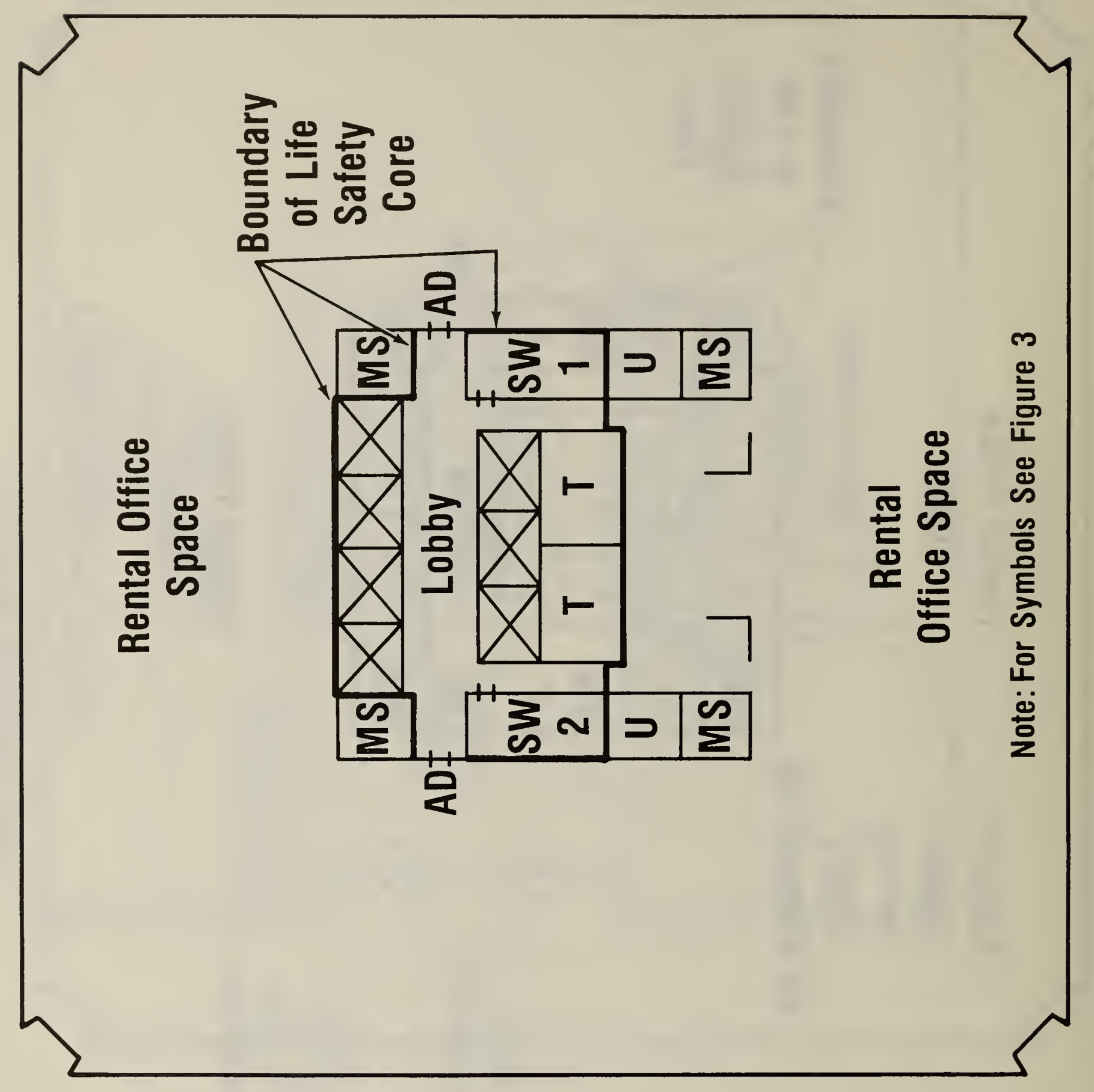

Figure 9 - Typical Floor Plan for Floors 20 through 36 of Building 5 


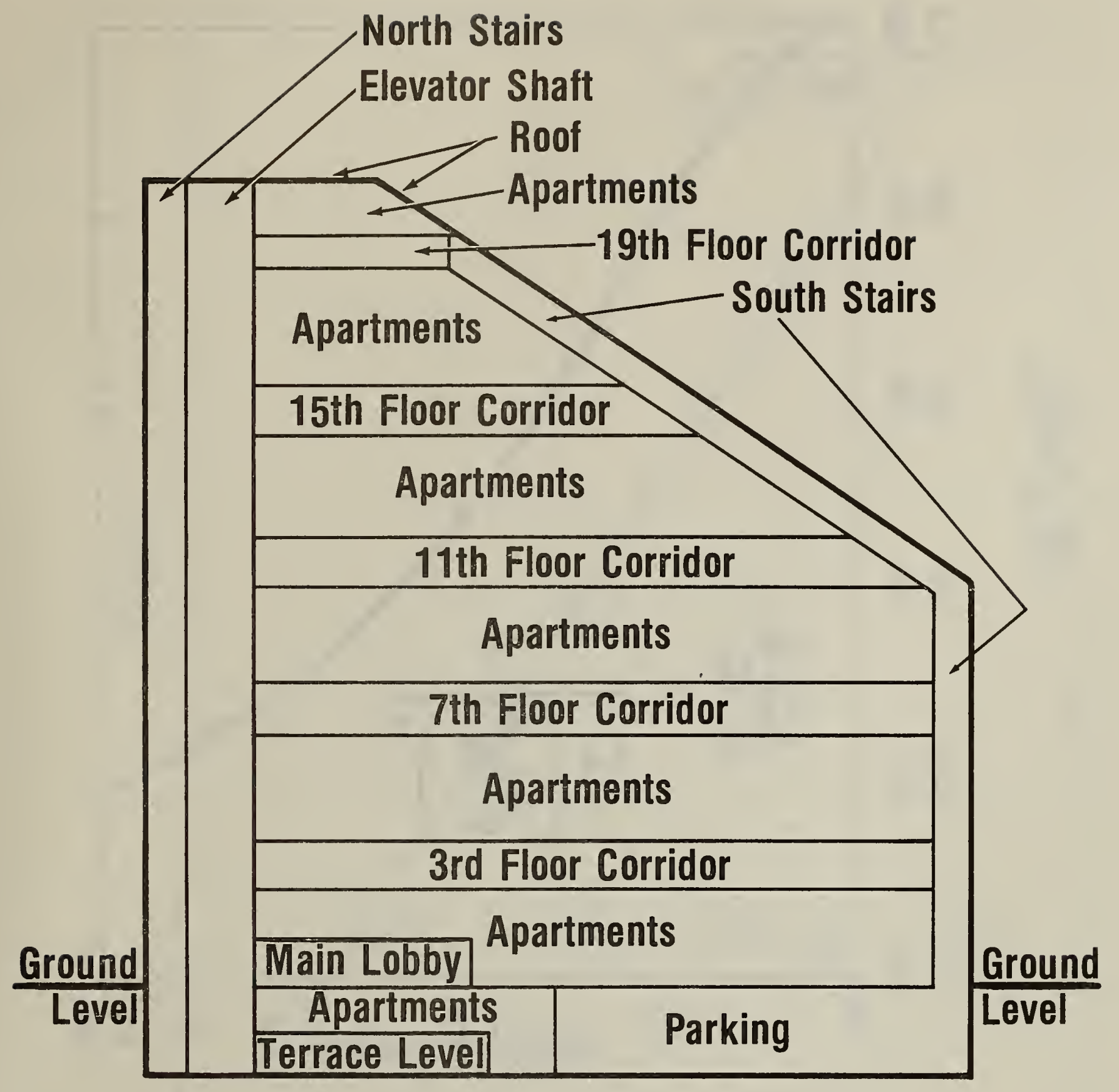

Figure 10 - Elevation of Building 6 


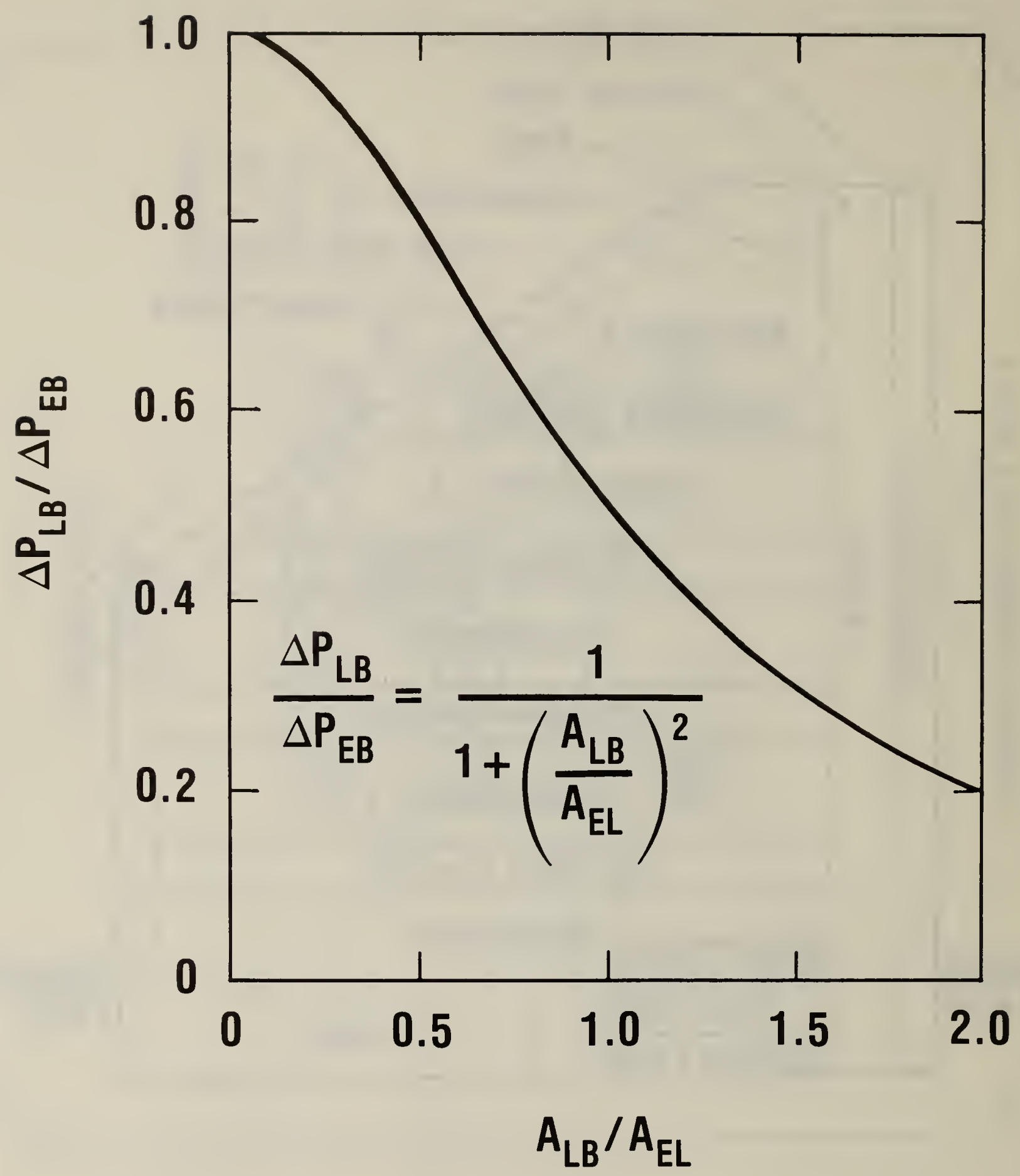

Figure 11 - Relationship between flow areas and pressure differences for an elevator lobby pressurized indirectly through the elevator shaft. 


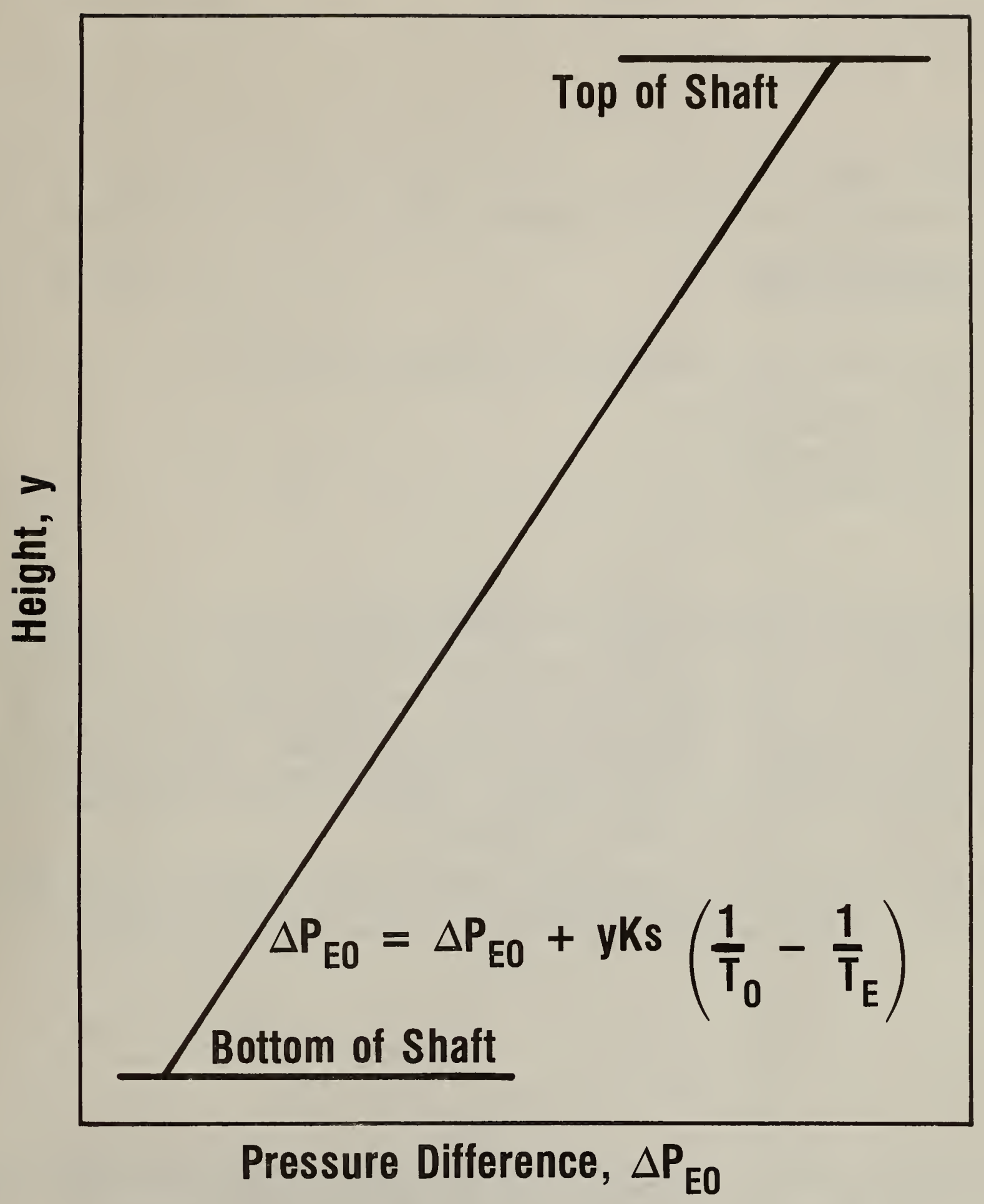

Figure 12 - Pressure difference from the shaft to the outside during winter conditions $\left(\mathrm{T}_{\mathrm{O}}<\mathrm{T}_{\mathrm{S}}\right)$. 
NBS.114A (REV. 2.BC)

U.S. DEPT. OF COMM.

BIBLIOGRAPHIC DATA

SHEET (See instructions)

1. PUBLICATION OR REPORT NO.

NBSIR - 83-2715

2. Performing Organ. Report No

3. Publication Date

June 1983

4. TITLE AND SUBTITLE

Smoke Control for Elevators

5. AUTHOR(S)

John H. Klote

6. PERFORMING ORGANIZATION (If joint of other than NBS, see instructions)

7. ContracuGrant No.

NATIONAL BUREAU OF STANDARDS

DEPARTMENT OF COMMERCE

8. Type of Report \& Period Covered

WASHINGTON, D.C. 20234

9. SPONSORING ORGANIZATION NAME AND COMPLETE ADDRESS (Strect, Cily, Stcte, ZIP)

Veterans Administration

Office of Construction $08 \mathrm{H}$

Washington, DC 20420

10. SUPPLEMENTARY NOTES

Document describes a computer program; SF-185, FIPS Software Summary, is attached.

11. ABSTRACT (A 200-word or less foctual summary of most significant information. If document includes a significant bibliography or literature survey, mention it here)

This paper is a second report on an ongoing project at NBS to investigate the use of elevators as a means of fire escape for the handicapped. The use of stairwells for fire evaculation poses a problem for people who cannot use stairs i because of physical disabilities. This paper discusses some of the major problems associated with the use of elevators as a means of fire exit and proposes a conceptual solution to those problems. A report is made on field tests of six buildings with elevator protection systems.

A simple relationship is developed for the pressure differences across the elevator shaft and across the elevator lobby for one type of elevator pressurization system. Vertical pressure profiles of such systems are also discussed.

12. KEY WORDS (Six to twelve entries; alphabetical order; capitalize only proper names; and separate key words by semicolons)

Building fires; egress; elevators (lifts); evaculation; handicapped;

pressurization; smoke control; stairwells.

13. AVAILABILITY

$\mathrm{X}$ Unlimited

For Official Distribution. Do Not Release to NTIS

Order From Superintendent of Documents, U.S. Government Printing Office, Washington, D.C. 20402.

4. NO. OF

PRINTED PAGES

60

15. Price

[X] Order From National Technical Information Service (NTIS), Springfield, VA. 2216I 

4

i) 